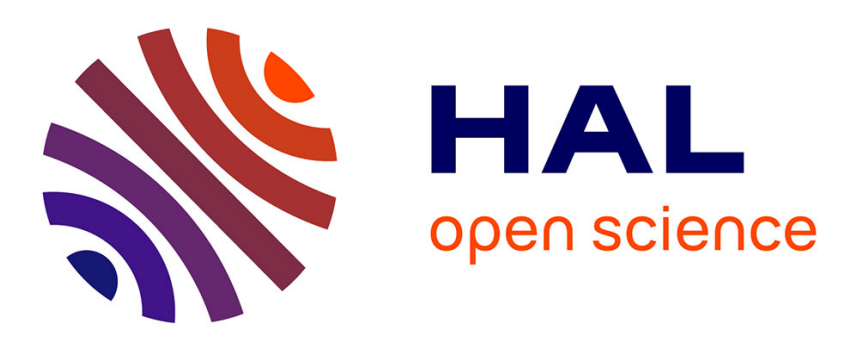

\title{
Effects of type of ration and allocation methods on the environmental impacts of beef-production systems
}

Thi Tuyet Hanh Nguyen, Hayo van Der Werf, Maguy Eugène, Patrick

Veysset, Jean Devun, , Michel Doreau

\section{- To cite this version:}

Thi Tuyet Hanh Nguyen, Hayo van Der Werf, Maguy Eugène, Patrick Veysset, Jean Devun, et al.. Effects of type of ration and allocation methods on the environmental impacts of beef-production systems. Livestock Science, 2012, 145 (1-3), pp.239-251. 10.1016/j.livsci.2012.02.010 hal-01209098

\section{HAL Id: hal-01209098 \\ https://hal.science/hal-01209098}

Submitted on 29 May 2020

HAL is a multi-disciplinary open access archive for the deposit and dissemination of scientific research documents, whether they are published or not. The documents may come from teaching and research institutions in France or abroad, or from public or private research centers.
L'archive ouverte pluridisciplinaire HAL, est destinée au dépôt et à la diffusion de documents scientifiques de niveau recherche, publiés ou non, émanant des établissements d'enseignement et de recherche français ou étrangers, des laboratoires publics ou privés. 


\title{
Effects of type of ration and allocation methods on the environmental impacts of beef-production systems
}

\author{
T.T.H. Nguyen ${ }^{\text {a,b,c,d }}$, H.M.G. van der Werf ${ }^{\text {b,c }}$, M. Eugène ${ }^{a}$, P. Veysset ${ }^{\text {a }}$, J. Devun ${ }^{\text {e }}$, \\ G. Chesneau ${ }^{\mathrm{d}}$, M. Doreau ${ }^{\mathrm{a}, *}$ \\ a INRA/VetAgro Sup, UMR 1213 Herbivores, F-63122 Saint-Genès-Champanelle, France \\ b INRA, UMR1069 Soil Agro and hydroSystem, F-35000 Rennes, France \\ c Agrocampus Ouest, F-35000 Rennes, France \\ d Valorex, La Messayais, F-35210 Combourtillé, France \\ e Institut de l'Elevage, F-63122 Saint-Genès-Champanelle, France
}

\section{A R T I C L E I N F O}

\section{Article history:}

Received 26 September 2011

Received in revised form 6 February 2012

Accepted 7 February 2012

\section{Keywords:}

Beef

Feeding strategy

Omega-3 supplementation

Life cycle assessment

Allocation method

Environmental services

\begin{abstract}
A B S T R A C T
Four complete beef-production systems consisting each of two stages were compared. The systems were formed by combining two diets for the cow-calf herd with finishing heifers stage - St (Standard) and 03 (maximising omega-3 fatty acids (FAs) using wrapped grass silage) with four diets for the bull-fattening herd stage - SM (silage maize starch), SML (silage maize starch plus linseed, rich in omega-3 FAs), FC (fibre-based concentrate), and SCL (starch-based concentrate plus linseed): St-SM, O3-SML, St-FC and O3-SCL. Life Cycle Assessments applied to these systems (from cradle to farm gate for a one-year period) estimated that their environmental impacts, per $\mathrm{kg}$ of carcass mass, ranged from 27.0 to $27.9 \mathrm{~kg} \mathrm{CO}$ equivalents (eq), 64.8-73.4 MJ, 94-98 $\mathrm{g} \mathrm{PO}_{4}^{3-}$ eq, 168-173 $\mathrm{g} \mathrm{SO}_{2}$ eq, 47-48 $\mathrm{m}^{2}$ year for climate change (CC, not including effect of land use and land-use change, LULUC), cumulative energy demand (CED), eutrophication potential, acidification potential and land occupation, respectively. Consideration of LULUC decreased CC from 8 to $10 \%$. Minor impact differences between these systems were observed, except for CED of St-FC, mainly because more energy was needed to dehydrate beet pulp and lucerne. CC of O3-SCL was 3\% lower than CC of St-SM. Most of the environmental impacts of beefproduction systems originated from the cow-calf herd with finishing heifers (73-97\%), which indicates that research on the reduction of environmental impacts of this type of beefproduction system should focus on this herd. For the cow-calf herd with finishing heifers, comparison of several allocation methods revealed that allocation method strongly affected the impacts per $\mathrm{kg}$ of carcass mass of the breeding bull and finished cull cows and, to a much lesser extent, those of fattened bulls and finished heifers. Consideration of both products (several animal types) and the ecosystem services supplied by these systems seems a promising perspective. This concept needs to be discussed and developed as an approach to consider the multifunctionality of farming systems.
\end{abstract}

(c) 2012 Published by Elsevier B.V.

\section{Introduction}

Worldwide the livestock sector was estimated to contribute $18 \%$ of global greenhouse gas (GHG) emissions, according to a Life Cycle Assessment (LCA) approach (Steinfeld et al., 2006).

\footnotetext{
* Corresponding author.

E-mail address: michel.doreau@clermont.inra.fr (M. Doreau).
}

Methane $\left(\mathrm{CH}_{4}\right)$ is the most significant (58-63\%) contributor to GHG emissions from beef systems (Veysset et al., 2010). Supplementation of diets with lipids is one of the most effective strategies for reducing enteric $\mathrm{CH}_{4}$ emissions by ruminants (Beauchemin et al., 2009). Martin et al. (2008) reported that feeding lipids rich in omega-3 fatty acids (FAs) from linseed significantly decreased enteric $\mathrm{CH}_{4}$ emissions from dairy cows. Enteric $\mathrm{CH}_{4}$ production by bulls fed a high-concentrate 
diet based on cereals supplemented with extruded linseed was reduced by $23 \%$ ( $\mathrm{g} / \mathrm{kg}$ live weight gain) in comparison with a high-concentrate diet based on fibre-rich co-products (Eugène et al., 2011). However, $\mathrm{CH}_{4}$ mitigation strategies must be assessed in a global vision of production systems to evaluate all GHG emissions and other environmental impacts (Martin et al., 2010).

In France, production systems for beef cows are based on grass, but fattening systems are diversified. For a same type of production, e.g. young bulls, there are several drivers for choosing a feeding system. The first one is the type of forage (based on grass or maize silage) and the proportion of forage relative to concentrate feed (Nguyen et al., in press). The second one is the nature of concentrates. Beef quality is a major consumer concern. A primary target in improving meat's nutritional quality is increasing its concentration of $n-3$ polyunsaturated fatty acids (FA) Doreau et al. (2011a). Indeed these FA play a role in the reduction of the risk of coronary heart disease and in infant development. Beef products can be enriched naturally with omega-3 FAs through provision of feed rich in linolenic acid, such as linseed, fresh grass or wrapped grass silage. Independently of meat quality, another strategy for beef fattening is the use of by-products rich in fibre, which avoids food competition with humans by reducing the use of cereals for animal feeding.

The main objective of this study was to investigate the environmental impacts, using a LCA approach, of a standard beefproduction system in France by comparing two systems, one based on feed rich in omega-3 FA and one with co-products rich in fibre. These beef production systems corresponded to a grassland-suckler cow-calf herd with finishing heifers and a bull-fattening herd. Grassland-based production systems contribute to sustainable rural development due to the ecosystem services they provide: landscape quality, biodiversity and carbon (C) sequestration. An additional objective was to analyse different allocation methods used to attribute environmental impacts to the co-products delivered by production systems. The choice of allocation method has generated much discussion in LCA studies on dairy systems regarding the co-products of milk and meat. In our beef-production systems, co-products were the types of meats from fattened bulls, finished heifers, finished cull cows, and a breeding bull. Ecosystem services supplied by these grassland-based production systems can also be considered as a co-product; we will explore this option.

\section{Materials and methods}

\subsection{Goal definition}

The goal of this study was to investigate four beef-production strategies practised in France, two of which produce omega-3 FA-enriched beef. These systems were characterised according to ration strategies for the suckler cow-calf herd with finishing heifers and the bull-fattening herd. We analysed the effect of different allocation methods, such as economic allocation (including the provision of ecosystem services or not), mass allocation, and allocation based on protein content, on potential environmental impacts for each co-product delivered by the system.

\subsection{Scope definition}

\subsubsection{Description of French beef production systems}

Each of the four production systems (Fig. 1) consists of two herds. The suckler cow-calf herd with finishing heifers (to be designated as cow-calf herd in the rest of this paper) produces weaned male calves or pre-fattened bulls, finished heifers, finished cull cows and a breeding bull. The weaned male calves or pre-fattened bulls are transferred to the bull-fattening herd, which yields fattened bulls. The systems are based on the Charolais breed as it represents $40 \%$ of the French sucklercow herd (Institut de l'Elevage, 2010). Two production methods were compared for the cow-calf herd. The first was the standard (St) cow-calf herd, which is most frequently practised in the Charolais basin. The second, the omega-3 (03) cow-calf herd, aimed to maximise the animals' omega-3 FA intake by using wrapped grass silage, which can be easily adopted by farmers. Four production methods were compared for the bull-fattening herd. The first was a standard bullfattening herd using a diet rich in starch based on silage maize (SM). The second was a bull-fattening herd using a diet rich in starch (based on silage maize) supplemented with linseeds (SML). The third was a bull-fattening herd using a fibre-based concentrate diet (FC). The last used a starchbased concentrate supplemented with a linseed diet (SCL). We combined the two herds to study the following four beefproduction systems: 1) St-SM, 2) St-FC, 3) O3-SML, and 4) O3-SCL. All rations were formulated to satisfy beef-cattle nutrient requirements according to animal characteristics and feedcomposition values, based on recommendations of INRA beef researchers and data tables (INRA, 2007). Details for both phases of the four systems are given below.

As suckler-cow farming practices in the Charolais basin are highly diverse, our systems were modelled based on "Charolais Beef Cattle Farm Networks" of the French Livestock Institute (Réseaux d'élevage Charolais, 2009) in consultation with beef researchers and experts. Both $\mathrm{St}$ and $\mathrm{O} 3 \mathrm{cow}$-calf herds consist of 70 cows that annually provide 62 weaned calves (Table 1). The replacement rate, defined as the proportion of heifers replacing cull cows, was 23\%. The cow-calf herd consists of four components for St and three components for 03. The first is reproduction; its output consists of weaned male calves, weaned female calves not used for replacement cull cows, cull cows and a breeding bull. The second component is rearing female calves from weaning ( 9 months) to finishing at 33 months. The third component is the finishing of cull cows, i.e. fattened before sending to the slaughterhouse. The last component (only for St) is pre-fattening of male calves for 2 months after weaning. The St and 03 cow-calf herd systems were built to reflect two types of actual farming practices which differ with respect to the calving period and the age at which male calves are sent to the bull-fattening herd. In the St, herd calves are born in February and weaned at 9 months, and male calves are pre-fattened for 2 months (reaching $430 \mathrm{~kg}$ live weight) with concentrate feed (20\% crude protein) and hay before passing to the bull-fattening herd. In the $\mathrm{O} 3$, herd calves are born in January and weaned at 9 months, and male calves (350 kg live weight) are sent directly to the bullfattening herd.

For feed management, both St and 03 are situated in the grassland zone of the Charolais basin and are classified as 
extensive systems with 1.2 livestock units per ha of forage area and 7.5 months grazing from April to November. One livestock unit is defined as an animal that consumes $5 \mathrm{t}$ dry matter (DM)/year (Gac et al., 2010a). Indoors in winter, the St herd is fed with hay and concentrates (mainly based on cereals produced on-farm and a mix meal which consisted of $30 \%$ soybean meal, $40 \%$ rapeseed meal and 30\% sunflower meal) produced off-farm, whereas the $\mathrm{O} 3$ herd is fed with wrapped grass silage, hay and concentrates (cereals and mix meal). Wrapped grass silage, i.e. grass silage at 55\% DM covered by plastic, has a higher omega-3 FA content than hay (Arrigo, 2010). Cull cows are finished for 100 days with a concentrate diet and hay (St herd) or wrapped grass silage (O3 herd). Weaned female calves which are not destined to be used for replacement cows are reared as heifers to be used for replacement until 29 months and then finished at pasture supplemented with cereals over 4 months to produce finished heifers.

Pre-fattened bulls from St are finished in the SM and FC bull-fattening herds. Weaned male calves from $\mathrm{O} 3$ are finished in the SML and SCL bull-fattening herds. The SM herd was located in the Pays de la Loire region (western France), which is a cereal-producing region. This phase was modelled based on "Typical Case: Young bull-fattening in Pays de la Loire" of the farm networks of the French Livestock Institute (Sarzeaud et al., 2009). The pre-fattened male calves are fed a highforage diet composed of $58 \%$ maize silage, $24 \%$ wheat, $15 \%$ soybean meal, $2 \%$ hay, and $1 \%$ minerals (DM basis), resulting in an average daily live weight gain (ADG) of $1.40 \mathrm{~kg} / \mathrm{d}$. The SML herd, also located in the Pays de la Loire region, is modelled on the SM herd with a portion of the wheat replaced by extruded linseed. The diet is composed of $58 \%$ maize silage, $17 \%$ wheat, $14 \%$ soybean meal, $8 \%$ Croquelin ${ }^{\circledR}$ (an extruded mix containing 50\% linseed, 30\% wheat bran and 20\% sunflower meal, Valorex, Combourtillé, France), 2\% hay, and 1\% minerals (DM basis). We assumed that animals in the SML herd are provided the same quantity of net energy for growth (i.e. $63 \mathrm{MJ} / \mathrm{d}$ ) as those in the SM herd. Since lipid supplementation is known to improve beef cattle performance (Clinquart et al., 1995) we assumed that the ADG of the SML herd (1.6\% lipid added) animals is $5 \%$ higher than that of animals in the SM herd.

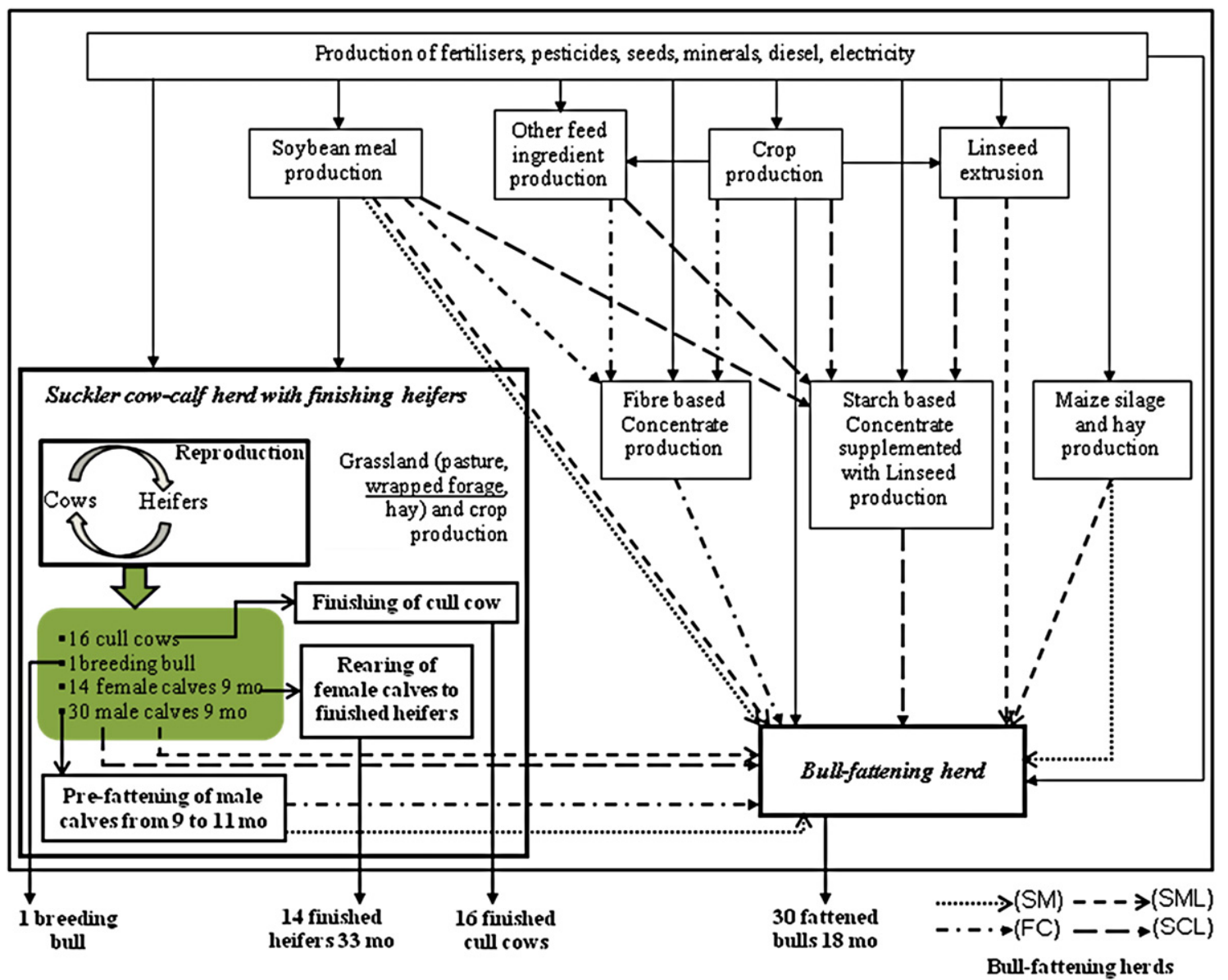

Fig. 1. "Cradle to farm-gate" life cycle of the four beef-production systems. St: Standard suckler cow-calf herd with finishing heifers. O3: Suckler cow-calf herd with finishing heifers enriched in omega-3 FAs through pasture and wrapped grass silage. SM: Standard bull-fattening herd using a diet rich in starch based on maize silage. SML: Bull-fattening herd using a diet rich in starch (based on maize silage) supplemented with linseeds. FC: Bull-fattening herd using a fibre-based concentrate diet. SCL: Bull-fattening herd using a starch-based concentrate supplemented with linseeds. Underline: Indicates this aspect is only present in O3 suckler cow-calf herd with finishing heifers. Pre-fattening of male calves from 9 to 11 months is only present in St suckler cow-calf herd with finishing heifers. Allocation methods were applied for these animals of the common phase, i.e. the reproduction component, before passing to the other periods. 
Table 1

Inputs and outputs of the four beef production systems.

\begin{tabular}{|c|c|c|c|c|}
\hline Inputs ( $\mathrm{t}$ dry matter) & St-SM & O3-SML & St-FC & O3-SCL \\
\hline Feed for cow-calf herd with finishing heifers & St & $\mathrm{O} 3$ & St & $\mathrm{O} 3$ \\
\hline Pastured grass & 276.5 & 270.8 & 276.5 & 270.8 \\
\hline Hay & 175.4 & 82.8 & 175.4 & 82.8 \\
\hline Wrapped grass silage & - & 91.8 & - & 91.8 \\
\hline Cereals & 76.5 & 66.9 & 76.5 & 66.9 \\
\hline Mix meal ${ }^{\mathrm{a}}$ & 6.8 & 4.8 & 6.8 & 4.8 \\
\hline Feed for bull-fattening herd & SM & SML & FC & $\mathrm{SCL}$ \\
\hline Maize silage & 31.7 & 38.5 & - & - \\
\hline Wheat & 15.0 & 13.0 & - & - \\
\hline Soybean meal & 9.2 & 10.3 & - & - \\
\hline Croquelin $\AA^{\mathrm{b}}$ & - & 5.9 & & \\
\hline Fibre-based concentrate $^{c}$ & - & - & 53.3 & - \\
\hline Starch-lipid-based concentrate ${ }^{c}$ & - & - & - & 58.7 \\
\hline Others & 2.1 & 2.6 & 7.9 & 8.5 \\
\hline \multirow[t]{2}{*}{ Animal outputs } & St-SM & O3-SML & St-FC & O3-SCL \\
\hline & \multicolumn{4}{|c|}{ Number of animal-kg live weight per animal } \\
\hline Breeding bull & $1-990$ & $1-990$ & $1-990$ & $1-990$ \\
\hline Finished cull cows & $16-798$ & $16-802$ & $16-798$ & $16-802$ \\
\hline Finished heifers & $14-695$ & $14-701$ & 14-695 & $14-701$ \\
\hline Fattened bulls & $30-720$ & $30-720$ & $30-720$ & $30-720$ \\
\hline
\end{tabular}

St: Standard suckler cow-calf herd with finishing heifers.

03: Suckler cow-calf herd with finishing heifers enriched in omega-3 FAs through pasture and wrapped grass silage.

SM: Standard bull-fattening herd using a diet rich in starch based on maize silage.

SML: Bull-fattening herd using a diet rich in starch (based on maize silage) supplemented with linseeds.

FC: Bull-fattening herd using a fibre-based concentrate diet.

SCL: Bull-fattening herd using a starch-based concentrate supplemented with linseeds.

a Mix meal composition: 30\% soybean meal, 40\% rapeseed meal and 30\% sunflower meal.

b Croquelin $₫$ : An extruded mix of $50 \%$ linseed, $30 \%$ wheat bran and $20 \%$ sunflower meal.

c See composition in Table S2 of Supplementary materials.

The other two diets are high in concentrates, and have been chosen because they represent two different options. One of them (FC) is rich in fibrous by-products; the interest is to use less cereals (which can feed humans) and to minimise the risk of digestive health problems such as acidosis. The other one (SML) is rich in cereals, and maximises the net energy value of the diet, by addition of lipids. The FC herd is located in the Champagne-Ardenne region (northern France), where cattle are frequently fed beet pulp and dehydrated lucerne. The diet (DM basis) of the FC herd consists of $13 \%$ straw and $87 \%$ concentrate including $22 \%$ wheat bran, $22 \%$ dehydrated lucerne and 21\% dehydrated beet pulp (Eugène et al., 2011). We assumed that animals in FC herd are provided $63 \mathrm{MJ} / \mathrm{d}$ of net energy for growth resulting in an ADG of $1.62 \mathrm{~kg} / \mathrm{d}$ (unpublished experimental data, Mialon M.M., pers. comm.). The SCL herd is located in the Aquitaine region (south-western France), where high-concentrate diets based on cereals are frequently used to fatten bulls. The SCL diet (DM basis) consists of 13\% barley straw and $87 \%$ concentrate rich in starch and lipids that includes $46 \%$ cereals and 6\% extruded linseed (Eugène et al., 2011) that provided $62 \mathrm{MJ} / \mathrm{d}$ of net energy for growth resulting in an ADG of $1.71 \mathrm{~kg} / \mathrm{d}$ (unpublished experimental data, Mialon M.M., pers. comm.).

The carcass yields of breeding bulls, finished heifers and finished cull cows were $57 \%, 56 \%$ and $54 \%$, respectively, according to expert knowledge and the slaughterhouse database of the INRA/Vet Agro Sup Herbivore Research Unit. The carcass yield of fattened bulls was 59\% according to Institut de l'Elevage (2011) and expert knowledge. All cereals produced on farms with cow-calf herds are consumed on the farm by the herd. Annual ration plans for cow-calf herds and bull-fattening herds and animal outputs of the four systems are presented in Table 1 and in supporting information Table S1 and Table S2.

\subsubsection{System boundary and delimitations}

This is a cradle-to-farm-gate study for a one-year period, i.e. the studied system includes the production and delivery of inputs used for grassland and cereals produced on-farm, of feed produced off-farm, herd management and associated upstream processes, emissions from the animals and manure storage. The application of manure for cereals and pasture is included, as are buildings. The transport and slaughter of animals leaving the system are not included. Veterinary medicines are not included because of lack of data.

\subsubsection{Functional unit and allocation of co-products}

The functional units were $1 \mathrm{~kg}$ of carcass mass at the farm exit gate for the whole systems, $1 \mathrm{~kg}$ live weight gain for each herd and 1 ha of land occupied (both for the whole system and each herd). Carcass mass produced was calculated by multiplying animal live weight at the farm gate by the specific carcass yields for each animal type. Economic allocation was used for feed ingredients resulting from processes yielding several co-products. Allocation was applied for animals 
Table 2

Outputs from two reproduction components of Standard and Omega-3 FA-enriched suckler cow-calf herds with finishing heifers and allocation factors following different allocation techniques.

\begin{tabular}{|c|c|c|c|c|c|c|c|c|c|c|}
\hline & \multicolumn{5}{|c|}{$\begin{array}{l}\text { Standard suckler cow-calf herds } \\
\text { with finishing heifers }\end{array}$} & \multicolumn{5}{|c|}{$\begin{array}{l}\text { Omega-3 FA-enriched suckler cow-calf } \\
\text { herds with finishing heifers }\end{array}$} \\
\hline & $\begin{array}{l}\text { Breeding } \\
\text { bull }\end{array}$ & $\begin{array}{l}\text { Cull } \\
\text { cow }\end{array}$ & $\begin{array}{l}\text { Weaned } \\
\text { female calf }\end{array}$ & $\begin{array}{l}\text { Weaned } \\
\text { male calf }\end{array}$ & Grassland & $\begin{array}{l}\text { Breeding } \\
\text { bull }\end{array}$ & $\begin{array}{l}\text { Cull } \\
\text { cow }\end{array}$ & $\begin{array}{l}\text { Weaned } \\
\text { female calf }\end{array}$ & $\begin{array}{l}\text { Weaned } \\
\text { male calf }\end{array}$ & Grassland \\
\hline Number of animals or grassland area (ha) & 1 & 16 & 14 & 30 & 82 & 1 & 16 & 14 & 30 & 81 \\
\hline Live weight mass of animals (kg) & 990 & 690 & 300 & 350 & - & 990 & 690 & 300 & 350 & - \\
\hline $\begin{array}{l}\text { Average price of animal products } 2004-2007 \\
\text { ( } € / \text { kg of live weight) or grassland subsidy } \\
\text { (€/ha of grassland) }\end{array}$ & 1.3 & 1.7 & 2.2 & 2.6 & 70 & 1.3 & 1.7 & 2.2 & 2.6 & 70 \\
\hline $\begin{array}{l}\text { Protein content in live weight mass }(\mathrm{g} / \mathrm{kg}) \\
\text { Allocation factors }\end{array}$ & 75 & 125 & 181 & 181 & - & 75 & 125 & 181 & 181 & - \\
\hline Mass allocation (\%) & 4 & 41 & 16 & 39 & - & 4 & 41 & 16 & 39 & - \\
\hline Allocation based on protein content (\%) & 2 & 33 & 19 & 46 & - & 2 & 33 & 19 & 46 & - \\
\hline $\begin{array}{l}\text { Economic allocation between animal } \\
\text { products (\%) }\end{array}$ & 2 & 32 & 18 & 48 & - & 2 & 32 & 18 & 48 & - \\
\hline $\begin{array}{l}\text { Economic allocation between animal products } \\
\text { and grassland subsidy (\%) }\end{array}$ & 2 & 29 & 16 & 44 & 9 & 2 & 29 & 16 & 44 & 9 \\
\hline
\end{tabular}

delivered from the reproduction component of the cow-calf herd (a breeding bull, cull cows, weaned female calves not used for replacement and weaned male calves). We compared different methods for the allocation of impacts to co-products:

1. Allocation on live weight mass. This implies that there is no difference in quality between live weight mass of different animal types. All live weight mass delivered from the reproduction component carried the same environmental burden.

2. Allocation based on protein mass. This was based on the protein content in the live weight mass (CORPEN, 2001) of each co-product delivered from the reproduction component of cow-calf herd.

3. Economic allocation. This was based on the market value of the live weight mass of each co-product delivered from the reproduction component. The prices per $\mathrm{kg}$ of live weight mass for each co-product were based on data from the French Livestock Institute for the 2004-2007 period (Réseaux d'élevage Charolais, 2004, 2005, 2006, 2007).

4. Economic allocation with agro-environmental subsidies. Agricultural activity, and in particular grassland-based production systems, has multiple functions such as food production, renewable natural-resource management, landscape and biodiversity conservation and contribution to the socioeconomic viability of rural areas (Renting et al., 2009). The agro-environmental measures of the European Union's Common Agricultural Policy (CAP) encourage farmers to maintain the environmental functions of agriculture. Thus, we attributed the environmental impacts of the studied system to these two functions. We used economic allocation based on beef product income as specified above and on agro-environmental subsidies for grassland according to the "Second Pillar" of the 2003 CAP reform in French conditions, to attribute environmental impacts to beef products (per kg of live weight mass) and to environmental services (per hectare of grassland). Subsidies or financial incentives vary between EU countries, and with time, therefore this calculation should be considered as an example for taking into account the effect of public policies on the environmental impact. Allocation techniques are summarised in Table 2.

\subsection{Life cycle inventory analysis}

\subsubsection{Feed production}

The cropping and grassland area was determined from total annual feed requirements for the beef production systems and the 4-year (2004-2007) average yields of pasture and crops based on the data of AGRESTE (2009). Grassland management was modelled on grassland production, the stocking rate of the production system and the amount of forage DM required for cattle in winter. The grassland area consisted of $88 \%$ permanent and $12 \%$ temporary pastures (AGRESTE, 2009). We assumed that permanent grassland did not require tilling and sowing operations. Permanent grassland had a yield of $5.6 \mathrm{t} \mathrm{DM} / \mathrm{ha} /$ year, $23 \%$ of which was harvested as conserved forage (hay and/or wrapped grass silage). Temporary grassland had a higher yield (8.3 t DM/ha/year, 75\% was harvested as conserved forage) and was renewed every 5 years by tillage and seeding. Grass not harvested as conserved forage was available for ingestion by animals during grazing. For several reasons (selective grazing, trampling of grass, unfavourable weather conditions) a part of the grass grown is not ingested, this "loss" corresponded to $31.5 \%$ of grass dry matter available for grazing. Losses during conservation for both hay and wrapped grass silage were assumed to be $6 \%$ of the initial DM. Apart from manure excreted on pasture during grazing, application rates of mineral and organic fertilisers were based on the data of Réseaux d'élevage Charolais (2009) with 1.2 livestock units per ha of forage area as the stocking rate. Pesticide use and other farm practices for grassland (Table S3) were based on a recent survey of agricultural practices (AGRESTE, 2006).

The period considered for crops begins with soil preparation for the specific crop and ends with soil preparation for the next crop. This period may include a catch crop. Data on input use and crop management (Table S3) were based on a recent survey of agricultural practices (AGRESTE, 2006). Data for soybean production (70\% soybean from central-western and 
Table 3

Estimation of enteric methane ( $\mathrm{g} / \mathrm{kg}$ dry matter intake) produced by different types of animal in different periods in St-SM and St-FC beef-production systems.

\begin{tabular}{|c|c|c|c|c|}
\hline & \multirow[t]{2}{*}{ Indoors } & \multicolumn{3}{|c|}{ Grazing season } \\
\hline & & Late spring & Summer & Autumn \\
\hline Multiparous cow & 22.6 & 20.0 & 16.9 & 15.8 \\
\hline Primiparous cow & 22.5 & 19.3 & 17.0 & 16.5 \\
\hline Heifer ( $>24$ months) & 21.5 & 22.3 & 18.5 & - \\
\hline Heifer (12-24 months) & 23.5 & 19.8 & 18.1 & 17.1 \\
\hline Heifer (<12 months) & 22.6 & - & - & 17.5 \\
\hline Breeding bull ( $>24$ months) & 21.6 & 19.1 & 16.5 & 15.2 \\
\hline Breeding bull (12-24 months) & 23.1 & 20.9 & 18.2 & 17.0 \\
\hline Breeding bull (<12 months) & 24.9 & - & - & 18.6 \\
\hline Pre-finisher & 18.7 & - & - & - \\
\hline Cull cow & 23.7 & - & - & - \\
\hline Growing heifer & - & - & 18.7 & 17.6 \\
\hline Fattening bull with maize silage & 25.1 & - & - & - \\
\hline Fattening bull with fibre-rich concentrate & 20.3 & - & - & - \\
\hline
\end{tabular}

St: Standard suckler cow-calf herd with finishing heifers.

SM: Standard bull-fattening herd using a diet rich in starch based on maize silage.

FC: Bull-fattening herd using a fibre-based concentrate diet

$30 \%$ from southern Brazil) and transport in Brazil was based on Prudêncio da Silva et al. (2010).

\subsubsection{Major feed ingredient production}

We considered that the transformation of soybean into soybean meal and oil occurred in Brazil based on data by Jungbluth et al. (2007) and Nemecek and Kägi (2007). According to the main French producer of extruded linseeds (Valorex, pers. comm.), the extrusion process required $60 \mathrm{kWh}$ of electricity and $0.21 \mathrm{kWh}$ of natural gas to produce $1 \mathrm{t}$ of Croquelin ${ }^{\circledR}$. According to information provided by a French dehydration cooperative (Coop de France Déshydratation, pers. comm.), dehydration of lucerne and beet pulp from 25\% to $90 \%$ DM required $6 \mathrm{GJ} / \mathrm{t}$ (mainly supplied by hard coal coke (59\%), natural gas (27\%) and light fuel oil (10\%)) of dehydrated product. Delivery of feed ingredients to the farm and feed mill and the delivery of concentrate feed to the farm were included. We assumed that the fibre-rich concentrate was produced in the Champagne-Ardenne region and starch and lipid-rich concentrate in the Aquitaine region.

\subsubsection{Buildings and operations}

This study included the production and transportation of materials required for the construction of buildings such as cattle housing, forage and manure storage based on the GES'TIM guide (Gac et al., 2010a). It was assumed that the cattle housing and manure storage had a 30-year life span and that the forage storage had a 50-year life span. However, energy use and emissions during the construction or disposal of the building were not included because of lack of information. The use of machines and energy for housing illumination, feeding, mulching, carrying manure out of housing and cleaning were included as farming operations, based on data from Dollé and Duyck (2007).

\subsubsection{Emissions and effect of land use and land-use change (LULUC) on soil $C$ balance}

Enteric $\mathrm{CH}_{4}$ emissions were estimated for each class of cattle according to the method developed by Vermorel et al. (2008) for cattle production in France and used for French gaseous-emissions inventories. This method uses animals' net-energy requirements, converted into metabolisable energy intake (MEI), and conversion factors from MEI to methane energy ( $Y^{\prime} \mathrm{m}=\mathrm{MJ} \mathrm{CH}_{4} / 100 \mathrm{MJ} \mathrm{MEI}$ ), to express $\mathrm{CH}_{4}$ emissions per $\mathrm{kg}$ of DM intake (DMI). This allowed the consideration of diet characteristics for each class of cattle (Table 3 ). This method is not applicable to diets rich in lipids. To include the effect of diets supplemented with lipids rich in omega-3 FAs on ruminants' enteric methane production, a $4.8 \%$ reduction factor of enteric methane production ( $\mathrm{g} \mathrm{CH} / \mathrm{kg} \mathrm{DMI}$ ) per percentage unit of added lipids was applied, based on results from a quantitative analysis (Martin et al., 2010).

The cow-calf herd was housed in deep bedding from December to April (4.5 months). The manure accumulated indoors was removed once a year. For bull-fattening herds, it was assumed that cattle remained indoors during the fattening period and that slurry was evacuated and stored outside the animal housing without a natural crust cover. Methane, nitrous oxide and ammonia emissions from manure produced by cattle in housing and during storage were included as part of livestock manure management, and emissions from manure deposited during grazing were included as part of grassland production. Nitrogen excretion was calculated as the difference between the animal's total nitrogen intake in feed and the nitrogen retained for growth (meat production) for each grazing and indoor period. For P-excreted on pasture, our estimation was based on Corpen (2001) taking into account the number of livestock units and the duration of grazing per ha of grassland. A summary of emission factors used for livestock, cropping and grassland production and their sources is presented in Table 4.

The effect of land use on $C$ sequestration in grassland was estimated according to Dollé et al. (2009) from measurements of C in soils summarised by Arrouays et al. (2002). For permanent grassland, i.e. grasslands older than 30 years, $C$ sequestration was estimated at $200 \mathrm{~kg} \mathrm{C} / \mathrm{ha} /$ year. We assumed that temporary grassland was maintained for 5 years and was followed by an annual crop for 2 years. $C$ sequestration was assumed to equal $500 \mathrm{~kg} \mathrm{C} /$ ha of temporary grassland/year and $\mathrm{C}$ release during the subsequent 2 years of annual crops was estimated at $1000 \mathrm{~kg} \mathrm{C} / \mathrm{ha} / \mathrm{year}$. As a result, there is a net $\mathrm{C}$ sequestration for temporary grassland of $100 \mathrm{~kg} \mathrm{C} / \mathrm{ha} / \mathrm{year}$. We assumed that 
Table 4

Emissions sources, equation or emission factor used and reference.

\begin{tabular}{|c|c|c|c|}
\hline \multicolumn{2}{|c|}{ Pollutant/source } & Equation/emission factor & Reference \\
\hline \multicolumn{4}{|c|}{ Manure management } \\
\hline \multirow[t]{3}{*}{ Direct $\mathrm{N}_{2} \mathrm{O}$} & \multicolumn{2}{|c|}{$=\mathrm{N}$ excreted $(\mathrm{kg}) \times \mathrm{EF}^{\mathrm{a}} \times 44 / 28$} & IPCC (2006) Tier 2 \\
\hline & Deep bedding manure & $\mathrm{EF}=0.07 \mathrm{~kg} \mathrm{~N} \mathrm{~N}_{2} \mathrm{O}-\mathrm{N} / \mathrm{kg} \mathrm{N}$ & \\
\hline & $\begin{array}{l}\text { Slurry without natural } \\
\text { crust cover }\end{array}$ & $\mathrm{EF}=0 \mathrm{~kg} \mathrm{~N} \mathrm{~N}_{2} \mathrm{O}-\mathrm{N} / \mathrm{kg} \mathrm{N}$ & \\
\hline \multirow[t]{3}{*}{ Indirect $\mathrm{N}_{2} \mathrm{O}$} & \multicolumn{2}{|c|}{$=\mathrm{N}$ excreted $(\mathrm{kg}) \times$ Frac $_{\mathrm{Gas}}{ }^{\mathrm{b}}(\%) \times 0.01 \times 44 / 28$} & IPCC (2006) Tier 2 \\
\hline & Deep bedding manure & Frac $_{\mathrm{Gas}}=30 \%$ & \\
\hline & $\begin{array}{l}\text { Slurry without natural } \\
\text { crust cover }\end{array}$ & Frac $_{\mathrm{Gas}}=40 \%$ & \\
\hline \multirow[t]{3}{*}{$\mathrm{CH}_{4}$} & \multicolumn{2}{|c|}{$\left.=\left[\left[\mathrm{GEI}^{\mathrm{c}} \times\left(1-\mathrm{DE}^{\mathrm{d}} \%\right) / 100+\mathrm{UE}^{*} \mathrm{GEI}^{\mathrm{e}}\right] \times 0.92\right) / 18.45\right] \times 0.17 \times 0.67 \times \mathrm{MCF}^{\mathrm{f}}(\%) / 100$} & IPCC (2006) Tier 2 \\
\hline & Deep bedding manure & $\mathrm{UE}=0.04 ; \mathrm{MCF}=4$ & \\
\hline & $\begin{array}{l}\text { Slurry without natural } \\
\text { crust cover }\end{array}$ & $\mathrm{UE}=0.04$ for SM and SML and 0.02 for SCL and FC; MCF $=27 \%$ & \\
\hline \multirow[t]{2}{*}{$\mathrm{NH}_{3}$} & In housing & $=0.12 \times \mathrm{N}$ excreted $(\mathrm{kg}) \times 17 / 14$ & Payraudeau et al. (2007) \\
\hline & In storage & $=0.06 \times \mathrm{N}$ remaining $(\mathrm{kg}) \times 17 / 14$ & \\
\hline \multicolumn{4}{|c|}{ Cropping and grassland production } \\
\hline Direct $\mathrm{N}_{2} \mathrm{O}$ & \multicolumn{2}{|c|}{$\begin{array}{l}=[[(\text { mineral } \mathrm{N}(\mathrm{kg})+\text { liquid } \mathrm{N}(\mathrm{kg})+\text { cattle manure } \mathrm{N}(\mathrm{kg})+\text { residue } \mathrm{N}(\mathrm{kg})] \times 0.01+\mathrm{N} \\
\text { deposited by grazing } \times 0.02)] \times 44 / 28\end{array}$} & IPCC (2006) Tier 2 \\
\hline Indirect $\mathrm{N}_{2} \mathrm{O}$ & \multicolumn{2}{|c|}{$\begin{array}{l}=[[[(\text { mineral N }(\mathrm{kg})+\text { liquid } \mathrm{N}(\mathrm{kg})] \times 0.1+\text { cattle manure } \mathrm{N}(\mathrm{kg}) \times 0.2] \times 0.01 \\
\left.+\mathrm{N}-\mathrm{NO}_{3}(\mathrm{~kg}) \times 0.0075\right] \times 44 / 28\end{array}$} & IPCC (2006) Tier 2 \\
\hline $\mathrm{NO}_{\mathrm{x}}$ & \multicolumn{2}{|c|}{$=0.21 \times \mathrm{N}_{2} \mathrm{O}(\mathrm{kg})$} & Nemecek and Kägi (2007) \\
\hline $\mathrm{NH}_{3}$ & \multirow{2}{*}{\multicolumn{2}{|c|}{$\begin{array}{l}=(0.02 \times \text { mineral } \mathrm{N}(\mathrm{kg})+0.08 \times \text { liquid } \mathrm{N}(\mathrm{kg})+0.076 \times \text { cattle manure } \mathrm{N}(\mathrm{kg})+0.08 \times \mathrm{N} \\
\text { deposited by grazing }) \times 17 / 14\end{array}$}} & Nemecek and Kägi (2007); \\
\hline & & & Payraudeau et al. (2007); CORPEN (2006) \\
\hline \multirow[t]{2}{*}{$\mathrm{NO}_{3}$} & Cropping & See values in Table S3 & Basset-Mens et al. (2007) \\
\hline & Grassland & $=8.77 \mathrm{e}^{0.003 \times \text { grazing days } / \mathrm{ha} / \mathrm{LU}^{\mathrm{g}}} \times 62 / 14$ & Vertès et al. (1997) \\
\hline \multirow[t]{2}{*}{ P leaching } & Cropping & $=0.07 \mathrm{~kg} \mathrm{P} /($ ha $\times$ year $)$ & Nemecek and Kägi (2007) \\
\hline & Grassland & $=0.06 \mathrm{~kg} \mathrm{P} /($ ha $\times$ year $)$ & \\
\hline \multirow[t]{3}{*}{ P run-off } & \multicolumn{2}{|c|}{$\begin{array}{l}=\mathrm{P} \text { run-off lost } \times\left[1+0.2 / 80 \times \text { mineral } \mathrm{P}_{2} \mathrm{O}_{5}(\mathrm{~kg})+0.4 / 80 \times \text { manure } \mathrm{P}_{2} \mathrm{O}_{5}(\mathrm{~kg})\right. \\
\left.+0.7 / 80 \times \mathrm{P}_{2} \mathrm{O}_{5} \text { deposited by grazing }(\mathrm{kg})\right]\end{array}$} & Nemecek and Kägi (2007) \\
\hline & Cropping & P run-off lost $=0.175 \mathrm{~kg} \mathrm{P} /($ ha $\times$ year $)$ & \\
\hline & Grassland & P run-off lost $=0.15 \mathrm{~kg} \mathrm{P} /($ ha $\times$ year $)$ & \\
\hline P erosion & \multicolumn{2}{|c|}{$\begin{array}{l}=10,000 \times(80 \times 0.033 \times 0.38 \times 0.65 \times \text { effect of the vegetation cover } \\
\text { factor }) \times 0.00095 \times 1.86 \times 0.2 \mathrm{~kg} \mathrm{P} /(\text { ha } \times \text { year })\end{array}$} & Nemecek and Kägi (2007) and \\
\hline \multicolumn{4}{|c|}{ a EF: emission factor for direct $\mathrm{N}_{2} \mathrm{O}$ emissions from manure management. } \\
\hline \multirow{2}{*}{\multicolumn{4}{|c|}{$\begin{array}{l}\text { b } \mathrm{Frac}_{\mathrm{Gac}} \text { : \% of managed manure nitrogen for production system that volatilises as } \mathrm{NH}_{3} \text { and } \mathrm{NO}_{\mathrm{x}} \text {. } \\
\text { c GEI: gross energy intake. }\end{array}$}} \\
\hline & & & \\
\hline \multicolumn{4}{|c|}{ d DE: digestibility of the feed. } \\
\hline \multicolumn{4}{|c|}{ e $\mathrm{UE} \times \mathrm{GEI}$ : urinary energy expressed as fraction of GEI. } \\
\hline \multicolumn{4}{|c|}{ f MCF: methane conversion factor from each manure-management system (in \%). } \\
\hline
\end{tabular}

other annual crop area was converted from permanent grassland more than 20 years ago and that agricultural practices for these crops had no effect on soil carbon. The part of Brazilian forest converted to soybean was estimated based on Prudêncio da Silva et al. (2010). In order to better conform to current practice with respect to the effect of land-use change on $C$ release due to conversion of Brazilian forest to cropland we decided to adopt a value of $740 \mathrm{t} \mathrm{CO}_{2}$ /ha as recommended in PAS 2050 (2008) among others, instead of the value of $120 \mathrm{tCO}_{2}$ /ha used in the Ecoinvent database (Jungbluth et al., 2007).

\subsection{Life cycle impact assessment}

The impact categories considered were climate change (CC), eutrophication potential (EP), acidification potential (AP), cumulative energy demand (CED) and land occupation (LO). The indicator value for each impact category was determined by multiplying the aggregated resources used and the aggregated emissions of each individual substance with a characterisation factor for each impact category to which it may potentially contribute, as implemented in the Ecoinvent ${ }^{\circledR}$ v2.0 database. CC is defined as the potential impact of gaseous emissions on the heat radiation absorption in the atmosphere. It was calculated according to the 100 -year global warming potential factors in $\mathrm{kg} \mathrm{CO}$ equivalent (eq), $\mathrm{CH}_{4}: 25, \mathrm{~N}_{2} \mathrm{O}: 298, \mathrm{CO}_{2}: 1$ (IPCC, 2007). Climate change does not take into account the effect of LULUC on $C$ sequestration in grassland and $C$ release due to conversion of Brazilian forest to cropland, whereas CC/LULUC takes into account these effects. CED accounts for the use of renewable and non-renewable energy resources by using the conversion efficiencies of primary energy carriers. Eutrophication covers all potential impacts of high environmental levels of macronutrients, in particular $\mathrm{N}$ and $\mathrm{P}$. EP was calculated using the generic $\mathrm{EP}$ factors in $\mathrm{kg} \mathrm{PO}_{4}$ eq, $\mathrm{NH}_{3}: 0.35, \mathrm{NO}_{3}: 0.1, \mathrm{NO}_{2}: 0.13, \mathrm{NO}_{\mathrm{x}}: 0.13, \mathrm{PO}_{4}: 1$ (Guinée et al., 2002). Acidifying pollutants have a wide variety of impacts on soil, groundwater, surface water, biological organisms, ecosystems and materials. AP was calculated using the average European AP factors in $\mathrm{kg} \mathrm{SO}_{2} \mathrm{eq}, \mathrm{NH}_{3}: 1.6, \mathrm{NO}_{2}: 0.5, \mathrm{NO}_{\mathrm{x}}$ : $0.5, \mathrm{SO}_{2}: 1.2$ (Guinée et al., 2002). Land occupation, including onfarm and off-farm area, refers to the loss of land as a resource in the sense of being temporarily unavailable for other purposes due to crop and grass production. 
Table 5

Impacts per $\mathrm{kg}$ of carcass mass and per ha of land occupation (both on-farm and off-farm) of the four beef-production systems.

\begin{tabular}{|c|c|c|c|c|c|c|c|c|c|}
\hline & & St-SM & O3-SML & St-FC & O3-SCL & St-SM & O3-SML & St-FC & O3-SCL \\
\hline & & \multicolumn{4}{|c|}{ per kg of carcass mass } & \multicolumn{4}{|c|}{ per ha of land occupation } \\
\hline Climate change & $\mathrm{kg} \mathrm{CO} 2$ eq & 27.8 & 27.7 & 27.9 & 27.0 & 5770 & 5880 & 5980 & 5780 \\
\hline Climate change/LULUC & $\mathrm{kg} \mathrm{CO} \mathrm{Cq}_{2}$ & 25.5 & 25.5 & 25.3 & 24.4 & 5290 & 5400 & 5420 & 5240 \\
\hline Cumulative energy demand & MJ & 64.8 & 68.4 & 73.4 & 71.1 & 13,470 & 14,510 & 15,720 & 15,260 \\
\hline Eutrophication & $\mathrm{kg} \mathrm{PO}_{4}^{3-}$ eq & 0.098 & 0.098 & 0.094 & 0.098 & 20.5 & 20.9 & 20.1 & 21.1 \\
\hline Acidification & $\mathrm{kg} \mathrm{SO}_{2}$ eq & 0.169 & 0.173 & 0.168 & 0.173 & 35.2 & 36.7 & 35.9 & 37.1 \\
\hline
\end{tabular}

St: Standard suckler cow-calf herd with finishing heifers.

03: Suckler cow-calf herd with finishing heifers enriched in omega-3 FAs through pasture and wrapped grass silage.

SM: Standard bull-fattening herd using a diet rich in starch based on maize silage.

SML: Bull-fattening herd using a diet rich in starch (based on maize silage) supplemented with linseeds.

FC: Bull-fattening herd using a fibre-based concentrate diet.

SCL: Bull-fattening herd using a starch-based concentrate supplemented with linseeds.

LULUC: Land use and land-use change.

\section{Results}

\subsection{Environmental impacts}

The environmental impacts of these systems are presented per $\mathrm{kg}$ of carcass mass and per ha of land occupied during a year (Table 5). Thus, carcass mass for each system consisted of fattened bulls, but also the corresponding output of the cowcalf herd (i.e. a breeding bull, finished heifers and finished cull cows, see Fig. 1). We observed minor differences between the four systems per $\mathrm{kg}$ of carcass mass and per ha $(+/-5 \%$ relative to St-SM) for all impact categories except CED. The lowest values per $\mathrm{kg}$ of carcass mass for CC and CC/LULUC were obtained in O3-SCL. The lowest values for CED were observed in St-SM. The highest CED values were observed in St-FC, with 13 and 17\% per $\mathrm{kg}$ of carcass mass and per ha, respectively, higher than those for St-SM. Consideration of the effect of LULUC induced a reduction of $9 \%$ of the CC impact for both functional units.

In our systems, enteric fermentation was the greatest contributor (39-41\%) to CC followed by grassland production (24-25\%), emissions from manure management (21-22\%), and production of other feed (9-10\%). Both building and farming operation only contributed $4 \%$ to CC (Fig. 2). The contribution of grassland production to CC/LULUC was lower than it was to $\mathrm{CC}$. For other impact categories, grassland production was the major contributor to the environmental impacts of production systems (58-63\% of EP, $46-47 \%$ of AP and $81-83 \%$ of LO). The production of other feed contributed $19-23 \%$ to EP, $12-13 \%$ to AP and $14-16 \%$ to LO. For CED impact, grassland production, other feed production, building and farming operation contributed approximately a third each. The emissions from manure contributed $17-18 \%$ and $37-39 \%$ to EP and AP, respectively.

For all scenarios, the cow-calf herd contributed most to the environmental impacts of the beef production system (Fig. 3). The contribution of the cow-calf herd to the impacts per $\mathrm{kg}$ of carcass mass was highest for LO (95\%), followed by CC (89\%), CC/LULUC (87\%), EP (88\%), AP (85\%) and lowest for CED (78\%). In general, environmental impacts to produce $1 \mathrm{~kg}$ of live weight gain in a bull-fattening herd (SM, SML, FC and SCL) were lower ( $-35 \%$ to $-89 \%$, according to the impact category) than those in a cow-calf herd (St and O3), except for CED in FC $(+55 \%)$ and SCL $(-6 \%)$ (Table 6). Nevertheless, when the environmental impacts of each herd are expressed per ha (Table S5), the impacts of the bull-fattening herd were 2-5 times higher than those of the cow-calf herd, except for CED of FC (14 times). Comparing St and O3, the impacts expressed per $\mathrm{kg}$ of live weight gain and per ha were higher for 03 . In comparing the four bull-fattening herds, all impacts expressed per ha and CED per $\mathrm{kg}$ of live weight gain of FC were highest.

\subsection{Effect of allocation methods on co-product impacts}

The systems delivered carcass mass of four types of animals: fattened bulls (50\% total carcass mass), finished heifers (21\%), finished cull cows (27\%) and a breeding bull (2\%). The relative impacts of each type of carcass mass in each system varied according to the allocation method used and the impact considered (Table 7 and Table S6). With mass allocation, for all systems studied, impact values for finished cull cows were highest, followed by those for breeding-bull carcass, finished heifers, and fattened bulls, except for CED of fattened bulls in St-FC. With other allocation methods, impact values for breeding-bull carcass were lowest in all systems. Whatever the allocation method used, impact values for fattened-bull carcass were lower than those for finished cull-cow and finished-heifer carcass, except for CED. For finished cull-cow and finished-heifer carcass, protein allocation yielded higher impact values than economic allocation, but for fattened-bull carcass the opposite occurred.

Economic allocation between beef-product income and agro-environmental subsidies resulted in the attribution of approximately $9 \%$ of the impacts of the reproduction component of beef-production systems to ecosystem services (Table 2). Impact of activities to maintain ecosystem services, expressed per ha of grassland, is presented in Table S7. The allocation of impacts to ecosystem services reduced impact values per $\mathrm{kg}$ of carcass by $6-9 \%$ relative to economic allocation without considering ecosystem services.

\section{Discussion}

\subsection{Comparison with previous studies}

Previous LCA studies on cradle-to-farm-gate beefproduction systems show a large variability between impacts. Climate-change impact of the whole suckler beef-production system, without consideration of LULUC, reported from studies in Brazil (Cederberg et al., 2009), the European Union (Nguyen 


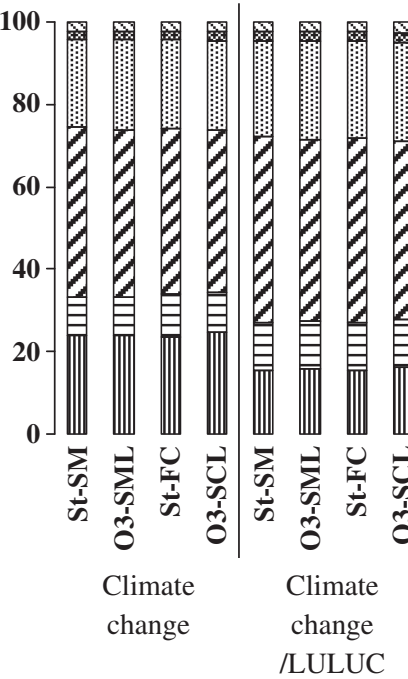

II Grassland production

国 Manure management
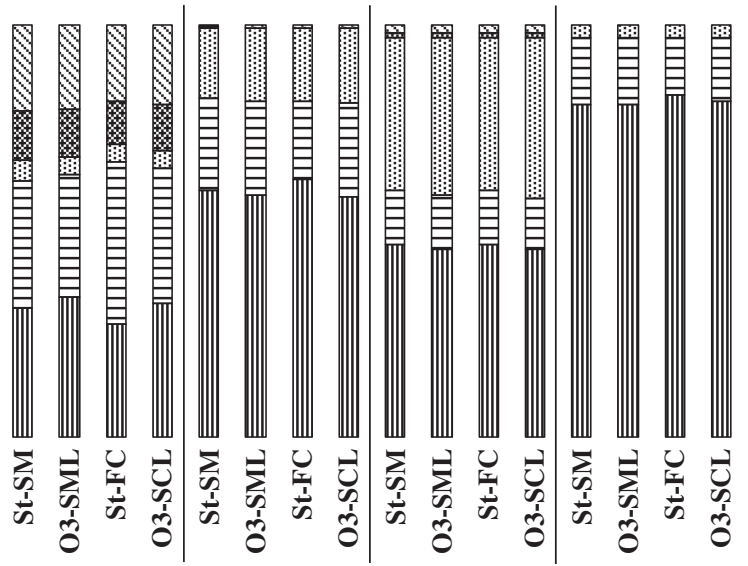

Cumulative Eutrophication energy demand

$\boxminus$ Other feed production

圈 Buildings
Land

occupation

\section{$\square$ Enteric fermentation}

จ Farming operation

Fig. 2. Contribution (in \%) of main components in environmental impacts of the four beef-production systems. St: Standard suckler cow-calf herd with finishing heifers. 03: Suckler cow-calf herd with finishing heifers enriched in omega-3 FAs through pasture and wrapped grass silage. SM: Standard bull-fattening herd using a diet rich in starch based on maize silage. SML: Bull-fattening herd using a diet rich in starch (based on maize silage) supplemented with linseeds. FC: Bull-fattening herd using a fibre-based concentrate diet. SCL: Bull-fattening herd using a starch-based concentrate supplemented with linseeds. LULUC: Land use and land-use change.

et al., 2010), the United Kingdom (Williams et al., 2006) and Canada (Beauchemin et al., 2010) were 28.2, 27.3, 25.3 and $21.7 \mathrm{~kg} \mathrm{CO}$ eq $/ \mathrm{kg}$ carcass mass, respectively. Our results (27.0-27.9; Table 5) are within the range obtained by these authors. Expressed per kg of live weight, CC impact varied from 15.3 to $15.9 \mathrm{~kg} \mathrm{CO}_{2}$ eq (data not shown) in our study, and are within the range obtained by Pelletier et al. (2010) in the United States (US; $14.8-19.2$ kg CO 2 eq) and by Gac et al. (2010b) and Veysset et al. $(2010,2011)$ in France $(14.1-20.2 \mathrm{~kg} \mathrm{CO}$ eq). For other impacts, our results per kg of carcass mass represented $38-60 \%$ for EP, $24-80 \%$ for AP, and $112-125 \%$ for LO relative to the impact values obtained by Williams et al. (2006) and Nguyen et al. (2010). Per ha of land occupation, our figures represented $88-92 \%$ for CC, 31-55\% for EP, and $20-72 \%$ for AP relative to the impact values converted from Nguyen et al. (2010) and Williams et al. (2006). Differences between the present study and literature data can be partly explained by differences between production system characteristics. Our cowcalf herds are extensive production systems in which nearly $80 \%$ of the surface was permanent grassland. In our systems, cows are 3-years-old at calving and provide an average of 4.3 calvings per lifetime; the more productive US or Canadian systems provide 6.7 and 6.5 calvings/cow, respectively. Another point is that in the system we studied, weaned female calves not used to replace cows are also reared as heifers to replace cows until the age of 29 months and then they are fattened on pasture until 33 months. Only weaned male calves are intensively fattened to produce bulls. In this study, the results for CC/LULUC are based on data for C sequestration in French agricultural soils; they are far below recent data on grassland C sequestration reported by Soussana et al. (2010) for certain European conditions and may underestimate the extent of net $C$ storage in soils. A minor reduction in CC impact (9\%) was obtained in this study regardless of the functional unit used. However, Pelletier et al. (2010) estimated a decrease in CC impact of $11 \%$ to $43 \%$ by considering C sequestration in improved pastures ( $120 \mathrm{~kg} \mathrm{C} / \mathrm{ha} /$ year) and unmanaged pastures ( $400 \mathrm{~kg} \mathrm{C} / \mathrm{ha} /$ year) under US conditions, but $\mathrm{C}$ loss from arable soils converted from pastures was not included. Higher compensation of CC impact (13-21\%) was obtained by Veysset et al. (2011) because $C$ sequestered in permanent grassland was higher ( $350 \mathrm{~kg} \mathrm{C} / \mathrm{ha}$ ), and $\mathrm{C}$ release was considered only for the proportion of cropland converted each year from temporary grassland.

For our systems, the relative contribution of the cow-calf herds to overall impacts was higher than for those reported by Pelletier et al. (2010). This is partially due to the higher replacement rate of cows in our systems and to the bullfattening herd, which concerned only weaned male calves. These results suggest that research emphasis should be put on the cow-calf herds to reduce the environmental impacts of this beef-production system. When the cow-calf herds and the bull-fattening herd are considered separately, the former uses much more land to produce $1 \mathrm{~kg}$ of live weight gain than the latter. However, these cow-calf herds were located on extensive grasslands in the Massif Central region with a low potential for annual crop production. Beef-cattle farming in this region, principally based on permanent grassland, plays an important role in sustaining the rural population and an attractive countryside. This is demonstrated by the low environmental impacts per ha of land for the cow-calf herds, which represented $19-55 \%$ of those for the bull-fattening herd, except for CED of St vs. FC (7\%). Our values for CC per kg of live weight gain for the bull-fattening herd were higher than those reported for a feedlot finishing phase by Phetteplace et al. (2001) in the United States and Doreau et al. (2011b) in France 


\begin{tabular}{|c|c|c|c|c|c|c|c|c|}
\hline Climate change & 90 & 10 & 88 & 12 & 89 & 11 & 90 & 10 \\
\hline Climate change/LULUC & 87 & 13 & 85 & 15 & 88 & 12 & 89 & 11 \\
\hline Cumulative energy demand & 83 & 17 & 80 & 20 & 73 & 27 & 77 & 23 \\
\hline Eutrophication & 89 & 11 & 85 & 15 & 93 & 7 & 85 & 15 \\
\hline Acidification & 87 & 13 & 84 & 16 & 87 & 13 & 84 & 16 \\
\hline \multirow[t]{2}{*}{ Land occupation } & 95 & 5 & 93 & 7 & 97 & $3][$ & 94 & 6 \\
\hline & St-S & & O3-S & & St-F & & O3-SC & \\
\hline
\end{tabular}

Fig. 3. Contribution (\%) of suckler cow-calf herd with finishing heifers (grey boxes) and of bull-fattening herd (white boxes) to the environmental impacts of the four beef-production systems. St: Standard suckler cow-calf herd with finishing heifers. 03: Suckler cow-calf herd with finishing heifers enriched in omega-3 FAs through pasture and wrapped grass silage. SM: Standard bull-fattening herd using a diet rich in starch based on maize silage. SML: Bull-fattening herd using a diet rich in starch (based on maize silage) supplemented with linseeds. FC: Bull-fattening herd using a fibre-based concentrate diet. SCL: Bull-fattening herd using a starch-based concentrate supplemented with linseeds. LULUC: Land use and land-use change.

but lower than those of Ogino et al. (2004) in Japanese conditions.

\subsection{Effect of omega-3 FA enrichment in the diet and of the proportion of concentrate on environmental impacts}

Both per kg of carcass mass and per ha of land occupation, minor differences between the four systems were observed for CC, EP and AP. This can be explained by the high contribution of the cow-calf herd (Fig. 2) on the environmental impacts of these systems and the minor differences between St and 03 (Tables 6 and S5). The production strategy (indoor finishing of cull cows and outdoor finishing of heifers not used for replacement) and the technical characteristics (grassland yield per ha, livestock units per ha of grassland, annual calving rate and replacement rate) were similar for these two cowcalf herds. The differences in the calving period (February or January), the age at which the male calf was sent to the fattening system (11 or 9 months) and the use of forage in winter (only hay or wrapped grass silage and hay) did not greatly differentiate the environmental impacts of St and $\mathrm{O} 3$ herds. Apart from replacing hay with wrapped grass silage, there is no other simple and economically viable means to increase omega-3 FAs, as in the suckler cow-calf herds with finishing heifers only a small amount of concentrate is fed to each animal. Among forages, differences in omega-3 FA content are mainly related to the mode of conservation and the age at cutting, and depend to a lesser extent on forage species (Van Ranst et al., 2009).

Differences between systems are larger when the bullfattening herd is considered alone. The use of rations with $87 \%$ concentrate for animals in FC and SCL herds increased CED both per $\mathrm{kg}$ of live weight gain and per ha, due to feedingredient production and feed processing, compared to the use of rations based on maize silage for animals in SM and SML herds. In the bull-fattening herd, CC was lower with a concentrate diet based on starch (SCL) than with a forage diet based on maize silage (SML) via the strong reduction of enteric methane related to a high proportion of concentrate and a higherthan-average daily gain for bulls. It is known that an increase in proportion of concentrate in the diet decreases enteric methane emissions from ruminants (Martin et al., 2010). Doreau et al. (2011b) reported that a strong decrease in enteric methane emissions of fattening bulls fed with an $86 \%$ concentrate diet based on maize grain induced a reduction of CC during the fattening phase compared to using a forage diet based on maize silage. However, a reduction of enteric methane produced by bulls fed with a concentrate diet based on fibre (FC) compared to bulls fed with a diet based on maize silage was countered by higher emissions of nitrous oxide and carbon dioxide from dehydration of beet pulp and lucerne. A minor reduction of CC, CED, $\mathrm{AP}$ and LO expressed per $\mathrm{kg}$ of live weight gain was obtained in SML compared to SM. Feeding a starch concentrate supplemented with extruded linseed (SCL) strongly reduced CC compared to that obtained in FC via a high reduction of enteric methane and a higher average daily gain for bulls in SCL and a higher carbon dioxide emission in FC due to dehydration of beet pulp and lucerne (Table S4). The SCL feeding strategy had higher EP impact per kg of live weight gain than the FC strategy, due to low nitrate emissions from the production of a fibre-rich concentrate compared to that of a concentrate rich in starch and lipids and a higher yield of lucerne and beet pulp compared to cereals. The high increase in CED of FC resulted from the energy required for lucerne and beet pulp dehydration to produce the fibre-rich concentrate. The impacts of the FC diet may have resulted more from current industrial processes of feedstuffs than from their chemical composition. It should be noted that the fibrerich concentrate contained $75 \%$ co-products (wheat bran, dehydrated beet pulp, wheat middlings, etc.) which can be digested by ruminants and thus avoid feed competition with other livestock and humans.

\subsection{Effect of allocation methods on co-product impacts}

The choice of allocation methodology for handling the coproducts has a decisive effect on LCA results (Cederberg and Stadig, 2003) and is still under debate. Beef-production systems produce four types of animals (fattened bulls, finished heifers, finished cull cows and a breeding bull) which differ not only in production methods but also in economic value and protein content of live weight mass. The question raised was how to determine the environmental impacts of each type of animal in each system. To our knowledge, no published LCA study has yet examined the environmental impacts of different types of animals produced in a beef-production system. According to the ISO recommendation, allocation should 
Table 6

Impacts per kg of live weight gain produced of two suckler cow-calf herds with finishing heifers and four bull-fattening herds.

\begin{tabular}{|c|c|c|c|c|c|c|c|}
\hline & & \multicolumn{2}{|c|}{$\begin{array}{l}\text { Suckler cow-calf herd } \\
\text { with finishing heifers }\end{array}$} & \multicolumn{4}{|c|}{ Bull-fattening herd } \\
\hline & & St & $\mathrm{O} 3$ & $\mathrm{SM}$ & SML & FC & SCL \\
\hline Climate change & $\mathrm{kg} \mathrm{CO}{ }_{2}$ eq & 17.5 & 18.3 & 8.6 & 8.0 & 9.1 & 6.3 \\
\hline Climate change/LULUC & $\mathrm{kg} \mathrm{CO} \mathrm{CO}_{2} \mathrm{eq}$ & 15.7 & 16.3 & 9.5 & 8.8 & 9.1 & 6.4 \\
\hline Cumulative energy demand & MJ & 37.8 & 41.0 & 33.1 & 32.3 & 58.5 & 38.7 \\
\hline Eutrophication & $\mathrm{g} \mathrm{PO}_{4}^{3-}$ eq & 62 & 63 & 32 & 33 & 19 & 33 \\
\hline Acidification & $\mathrm{g} \mathrm{SO}_{2}$ eq & 103 & 109 & 67 & 65 & 63 & 65 \\
\hline Land occupation & $\mathrm{m}^{2}$ year & 32.1 & 33.1 & 7.8 & 7.4 & 3.6 & 6.3 \\
\hline
\end{tabular}

St: Standard suckler cow-calf herd with finishing heifers.

03: Suckler cow-calf herd with finishing heifers enriched in omega-3 FAs through pasture and wrapped grass silage.

SM: Standard bull-fattening herd using a diet rich in starch based on maize silage.

SML: Bull-fattening herd using a diet rich in starch (based on maize silage) supplemented with linseeds.

FC: Bull-fattening herd using a fibre-based concentrate diet.

SCL: Bull-fattening herd using a starch-based concentrate supplemented with linseeds.

LULUC: Land use and land-use change.

be avoided whenever possible by dividing the main process into sub-processes or by expanding the production system to include additional functions related to the co-products (ISO, 2006). Where allocation cannot be avoided, the allocation should be performed by determining physical causal relationships (JRC, 2010) or the market value of the co-products. For dairy-production systems, biological and economic allocation have often been used to allocate impacts of milk and meat products than mass allocation (Yan et al., 2011) and protein allocation, although ISO standards prefer mass and protein allocation to economic allocation. In fact, allocation based on biological rules reflects a physical causal relationship and is recommended first among other physical causalities such as mass and protein. Protein allocation allows comparison of animal products through protein content (de Vries and de Boer, 2009) and reflects that a main function of the beefproduction sector is to provide humans with edible protein.
In LCA studies, economic allocation is the most common method (de Vries and de Boer, 2009) because products are manufactured corresponding to a demand reflected in their market value (Jolliet et al., 2010).

We therefore analysed the effects of mass, protein and economic allocation on the impacts of four types of animals produced in each system. The allocation approach strongly affected the impacts per $\mathrm{kg}$ of carcass mass of breeding bull and, to a much lesser extent, of finished cull cows, fattened bulls and finished heifers. This is because the live weight mass of a breeding bull has lower protein content and economic value than that of the other animal types. The difference in impacts was lowest between protein and economic allocation for fattened bulls, finished cull cows and the breeding bull, and was lowest between mass and economic allocation for finished heifers. Economic allocation could thus be considered a reference allocation method in beef systems.

Table 7

Climate-change impacts and cumulative energy demand per kg of carcass mass of four types of animals delivered from the four production systems according to four allocation methods.

\begin{tabular}{|c|c|c|c|c|c|c|c|c|c|c|}
\hline & \multicolumn{4}{|c|}{$\begin{array}{l}\text { Fattened } \\
\text { bull }\end{array}$} & \multicolumn{2}{|c|}{$\begin{array}{l}\text { Finished } \\
\text { heifer }\end{array}$} & \multicolumn{2}{|c|}{$\begin{array}{l}\text { Finished } \\
\text { cull cow }\end{array}$} & \multicolumn{2}{|c|}{$\begin{array}{l}\text { Breeding } \\
\text { bull }\end{array}$} \\
\hline & St-SM & O3-SML & St-FC & O3-SCL & St & $\mathrm{O} 3$ & St & $\mathrm{O} 3$ & St & $\mathrm{O} 3$ \\
\hline \multicolumn{11}{|l|}{ Climate-change $\left(\mathrm{kg} \mathrm{CO} \mathrm{Cl}_{2}\right.$ eq) } \\
\hline Mass allocation & 22.4 & 22.1 & 22.8 & 20.6 & 31.0 & 31.2 & 34.8 & 34.9 & 31.9 & 32.2 \\
\hline Protein allocation & 25.0 & 24.7 & 25.4 & 23.2 & 33.6 & 33.8 & 29.2 & 29.3 & 15.5 & 15.6 \\
\hline Economic allocation & 25.9 & 25.6 & 26.3 & 24.1 & 31.9 & 32.1 & 28.6 & 28.6 & 19.6 & 19.9 \\
\hline Economic allocation with subsidies & 24.2 & 24.0 & 24.5 & 22.5 & 28.8 & 29.1 & 26.3 & 26.4 & 17.8 & 18.1 \\
\hline \multicolumn{11}{|l|}{ Cumulative energy demand (MJ) } \\
\hline Mass allocation & 59.1 & 62.7 & 76.5 & 68.3 & 63.5 & 66.9 & 76.0 & 79.5 & 69.3 & 73.7 \\
\hline Protein allocation & 64.8 & 68.7 & 82.2 & 74.3 & 69.1 & 72.9 & 63.9 & 66.8 & 33.7 & 35.8 \\
\hline Economic allocation & 66.7 & 70.8 & 84.1 & 76.4 & 65.5 & 69.1 & 62.5 & 65.2 & 42.7 & 45.4 \\
\hline Economic allocation with subsidies & 63.0 & 67.0 & 80.4 & 72.5 & 59.3 & 62.5 & 57.5 & 60.1 & 38.8 & 41.4 \\
\hline
\end{tabular}

St: Standard suckler cow-calf herd with finishing heifers.

03: Suckler cow-calf herd with finishing heifers enriched in omega-3 FAs through pasture and wrapped grass silage.

SM: Standard bull-fattening herd using a diet rich in starch based on maize silage.

SML: Bull-fattening herd using a diet rich in starch (based on maize silage) supplemented with linseeds.

FC: Bull-fattening herd using a fibre-based concentrate diet.

SCL: Bull-fattening herd using a starch-based concentrate supplemented with linseeds.

Beef-production systems: 1) St-SM, 2) O3-SML, 3) St-FC, and 4) O3-SCL. 
The process of CAP reforms has reoriented the development of agriculture in Europe towards the principles of rural development and agricultural multifunctionality (Daniel and Perraud, 2009). The "Second Pillar" of the CAP focuses on agroenvironmental subsidies. These subsidies are intended for landscape management, nature conservation, environmental protection, biodiversity and rural development and concretely reflect social demand toward maintaining grassland with a low stocking rate. LCA has been criticised for considering only "negative" impacts and excluding the positive impacts of agriculture (e.g. Bockstaller et al., 2010). We do believe that this multifunctionality of agriculture, including the provision of ecosystem services, can be included simply by considering such services as coproducts. We therefore allocated the impacts of the systems to both their production function (expressed in animal products) and the provision of environmental services (expressed in grassland area). This method resulted in attribution of $9 \%$ of the environmental impacts of the reproduction component of beefproduction systems to the activities for maintaining ecosystem services. Frequent modifications of CAP reforms result in the adaptation of farming practices to maximise the subsidies (Bélard and Liénard, 2001). Clearly, a modification in agroenvironmental subsidies for grassland reflects a modification in social demand regarding the contribution of grasslands on public goods such as biodiversity and landscapes. The allocation of impacts to animal products and to the activities for maintaining ecosystem services will be modified according to the policy adopted. This approach is an initial attempt to consider the ecosystem services provided by farming systems as co-products when estimating the environmental impacts of animal production. A comparable approach has been suggested for Spanish sheep farming systems (Ripoll-Bosch et al., 2011).

\section{Conclusions}

Our cradle-to-farm-gate study shows that most environmental impacts of beef-production systems emanate from the suckler cow-calf herd with finishing heifers. As a result of the considerable contribution of this herd to the entire system's impacts and the small differences between the standard and omega-3 FA-enriched herds, the environmental impacts of the four investigated systems did not clearly differ, even though those of the bull-fattening herds varied widely. Including effect of land use and land-use change induced a reduction of $9 \%$ of climatechange impacts for the entire production system. Use of linseed for the bull-fattening herd did not influence the systems' environmental impacts. This study further revealed that more research for mitigation of the environmental impacts of beef production should focus on the suckler cow-calf herd with finishing heifers.

The allocation approach strongly affected the impacts per $\mathrm{kg}$ of carcass mass of a breeding bull and finished cull cows and, to a much lesser extent, those of fattened bulls and finished heifers. The application of economic allocation considering agroenvironmental subsidies has shown that the environmental services of farming systems can be considered in LCA studies, which thus can include the positive impacts of farming systems, such as landscape management and biodiversity conservation. This concept needs to be discussed and developed to highlight and preserve the environmentally friendly aspects of farming systems.
Supplementary materials related to this article can be found online at doi:10.1016/j.livsci.2012.02.010.

\section{Conflict of interest}

We do not have any actual or potential conflict of interest including any financial, personal or other relationships with other people or organizations within three years of beginning the submitted work that could inappropriately influence, or be perceived to influence, their work.

\section{Acknowledgments}

The first author was granted by Valorex, Combourtillé, France. The authors gratefully acknowledge Florence GarciaLaunay for simulating cattle N-retention rates and MarieMadeleine Mialon for providing data on bull-fattening performance (INRA/Vet Agro Sup, UMR 1213 Herbivores).

\section{References}

AGRESTE, 2006. Enquête pratiques culturales. Available online: http:// agreste.maapar.lbn.fr/ReportFolders/ReportFolders.aspx.

AGRESTE, 2009. Statistique agricole annuelle/cultures fourragères. Available online: http://agreste.maapar.lbn.fr/TableViewer/tableView.aspx.

Arrigo, Y., 2010. Matière grasse et composition en acides gras des fourrages conservés. Rech. Agron. Suisse 1, 366-371.

Arrouays, D., Balesdent, J., Germon, J.C., Jayet, P.A., Soussana, J.F., Stengel, P., 2002. Contribution à la lutte contre l'effet de serre. Stocker du carbone dans les sols agricoles de France? Expertise scientifique collective. INRA report. 332 pp.

Basset-Mens, C., van der Werf, H.M.G., Robin, P., Morvan, T., Hassouna, M., Paillat, J.M., Vertès, F., 2007. Methods and data for the environmental inventory of contrasting pig production systems. J. Cleaner Prod. 15, 1395-1405.

Beauchemin, K.A., McAllister, T.A., McGinn, S.M., 2009. Dietary mitigation of enteric methane from cattle. CAB Rev. 4, 1-18.

Beauchemin, K.A., Janzen, H.H., Little, S.M., McAllister, T.A., McGinn, S.M., 2010. Life cycle assessment of greenhouse gas emissions from beef production in western Canada: a case study. Agric. Syst. 103, 371-379.

Bélard, J.F., Liénard, G., 2001. Place de l'herbe dans les élevages bovins et ovins du Massif Central nord (Auvergne et Limousin). Importance des différentes primes. Fourrages 165, 45-60.

Bockstaller, C., Espagnol, S., Guichard, L., Petit, J., Raison, C., Vertès, F., 2010. Stratégies de choix des méthodes et outils d'évaluation environnementale en systèmes d'élevage. In: Espagnol, S., Leterme, P. (Eds.), Elevages et environnement. Editions Quae, Versailles, France, pp. 15-64.

Cederberg, C., Stadig, M., 2003. System expansion and allocation in life cycle assessment of milk and beef production. Int. J. LCA 8, 350-356.

Cederberg, C., Meyer, D., Flysjo, A., 2009. Life cycle inventory of greenhouse gas emissions and use of land and energy in Brazilian beef production. SIK Report 792.

Clinquart, A., Micol, D., Brundseaux, C., Dufrasne, I., Istasse, L., 1995. Utilisation des matières grasses chez les bovins à l'engraissement. INRA Prod. Anim. 8, 29-42.

CORPEN, 2001. Estimation des flux d'azote, de phosphore et de potassium associés aux bovins allaitants et aux bovins en croissance ou à l'engrais, issus de troupeaux allaitants et laitiers et à leur système fourrager. Groupe alimentation animale. Available online: http://www.developpementdurable.gouv.fr/IMG/pdf/DGALN_2001_06_flux_bovin_engrais.pdf.

CORPEN, 2006. Les émissions d'ammoniac et de gaz azotés à effet de serre en agriculture. Groupe Azote, Available online: http://www.developpementdurable.gouv.fr/IMG/pdf/DGALN_2006_10_ammoniac_gaz_azote.pdf.

Daniel, F.J., Perraud, D., 2009. The multifunctionality of agriculture and contractual policies. A comparative analysis of France and the Netherlands. J. Environ. Manage. 90, S132-S138.

De Vries, M., de Boer, I.J.M., 2009. Comparing environmental impacts for livestock products: a review of life cycle assessments. Livest. Sci. 128, 1-11.

Dollé, J.B., Duyck, J.B., 2007. Les consommations d'énergie en bâtiments d'élevage bovin. Compte rendu final $N^{\circ} 050733$ 008, Institut de l'élevage. Available online: http://www.inst-elevage.asso.fr/IMG/pdf_CR_050733008.pdf.

Dollé, J.B., Gac, A., Le Gall, A., 2009. L'empreinte carbone du lait et de la viande. Renc. Rech. Ruminants 16, 233-236.

Doreau, M., Bauchart, D., Chilliard, Y., 2011a. Enhancing fatty acid composition of milk and meat through animal feeding. Anim. Prod. Sci. 51, 19-29. 
Doreau, M., van der Werf, H.M.G., Micol, D., Dubroeucq, H., Agabriel, J., Rochette, Y., Martin, C., 2011b. Enteric methane production and greenhouse gases balance of diets differing in concentrate in the fattening phase of a beef production system. J. Anim. Sci. 89, 2518-2528.

Eugène, M., Martin, C., Mialon, M.M., Krauss, D., Renand, G., Doreau, M., 2011. Dietary linseed and starch supplementation decreases methane production of fattening bulls. Anim. Feed. Sci. Technol. 166-167, 330-337.

Gac, A., Cariolle, M., Deltour, L., Dollé, J.B., Espagnol, S., Flénet, F., Guingand, N., Lagadec, S., Le Gall, A., Lellahi, A., Malaval, C., Ponchant, P., Tailleur, A., 2010a. GES'TIM - Guide méthodologique pour l'estimation des impacts des activités agricoles sur l'effet de serre. Réalisé dans le cadre du projet "Gaz à Effet de Serre et Stockage de Carbone en exploitations agricoles» (CASDAR 6147).

Gac, A., Manneville, V., Raison, C., Charroin, T., Ferrand, M., 2010b. L'empreinte carbone des élevages d'herbivores: présentation de la méthodologie d'évaluation appliquée à des élevages spécialisés lait et viande. Renc. Rech. Ruminants 17, 335-342.

Guinée, J.B., Gorrée, M., Heijungs, R., Huppes, G., Kleijn, R., de Koning, A., van Oers, L., Wegener Sleeswijk, A., Suh, S., Udo de Haes, H.A., de Bruijn, H., van Duin, R., Huijbregts, M.A.J., 2002. Life Cycle Assessment. An operational guide to the ISO Standards. Centre of Environmental Science, Leiden University, Leiden, The Netherlands.

INRA, 2007. Alimentation des bovins, ovins et caprins. Besoins des animaux, valeurs des aliments. Tables INRA 2007. Eds. Quae, 307p.

Institut de l'Elevage, 2010. Chiffres clés 2010 : Productions bovines lait \& viande. Available online: http://www.inst-elevage.asso.fr/IMG/pdf_Chiffres_cles_ bovins_2010.pdf.

Institut de l'Elevage, 2011. Production de jeunes bovins de races à viande et de races laitières, 13 fiches de références sur les itinéraires techniques. Available online: http://www.inst-elevage.asso.fr/IMG/pdf_CR_160832029avec_nveau_logo.pdf.

IPCC (Intergovernmental Panel on Climate Change), 2006. Guidelines for national greenhouse gas inventories. Volume 4: Agriculture, Forestry and Other Land Use.

IPCC, 2007. IPCC Fourth Assessment Report (AR4) - Climate Change 2007. In: Solomon, S., Qin, D., Manning, M., Chen, Z., Marquis, M., Averyt, K.B., Tignor, M., Miller, H.L. (Eds.), Working Group I Report "The Physical Science Basis". Cambridge University Press, Cambridge, UK, New York, NY, USA.

ISO (International Organization for Standardization), 2006. Environmental Management - Life Cycle Assessment: Requirements and Guidelines, Geneva.

Jolliet, O., Saadé, M., Crettaz, P., Shaked, S., 2010. Analyse du cycle de vie : comprendre et réaliser un écobilan. Presses polytechniques et universitaires romandes, Lausanne, Switzerland, $302 \mathrm{pp}$

JRC (Joint Research Centre), 2010. ILCD Handbook. General Guide for Life Cycle Assessment - Detailed Guidance. European Commision, Institute for Environment and Sustainability, Ispra, Italie.

Jungbluth, N., Chudacoff, M., Dauriat, A., Dinkel, F., Doka, G., Faist Emmenegger, M., Gnansounou, E., Kljun, N., Schleiss, K., Spielmann, M., Stettler, C., Sutter, J., 2007. Life Cycle Inventories of Bioenergy. Ecoinvent Report No 17. Swiss Centre for the Life Cycle Inventories, Dübendorf, Switzerland.

Martin, C., Rouel, J., Jouany, J.P., Doreau, M., Chilliard, Y., 2008. Methane output and diet digestibility in response to feeding dairy cows crude linseed, extruded linseed, or linseed oil. J. Anim. Sci. 86, 2642-2650.

Martin, C., Morgavi, D.P., Doreau, M., 2010. Methane mitigation in ruminants: from the rumen microbes to the farm scale. Animal 4, 351-365.

Nemecek, T., Kägi, T., 2007. Life cycle inventories of Swiss and European Agricultural production systems. Final Report Ecoinvent No 15. Agroscope Reckenholz Taenikon Research Station ART, Swiss Centre for Life Cycle Inventories, Zurich and Dübendorf, Switzerland.

Nemecek, T., Heil, A., Huguenin, O., Meier, S., Erzinger, S., Blaser, S., Dux, D., Zimmermann, A., 2003. Life cycle inventories of agricultural production systems. Final Report Ecoinvent 2000 No 15. FAL Reckenholz, FAT Tänikon, Swiss Centre for Life Cycle Inventories, Dübendorf, Switzerland.

Nguyen, T.L.T., Hermansen, J.E., Mogensen, L., 2010. Environmental consequences of different beef production systems in the EU. J. Cleaner Prod. $18,756-766$

Nguyen, T.T.H., van der Werf, H.M.G., Doreau, M., in press. Life cycle assessment of three bull-fattening systems: effect on ranking of impact categories. J. Agric. Sci. doi:10.1017/S0021859612000123.

Ogino, A., Kaku, K., Osada, T., Shimada, K., 2004. Environmental impacts of the Japanese beef-fattening system with different feeding lengths as evaluated by a life-cycle assessment method. J. Anim. Sci. 82, 2115-2122.
PAS 2050, 2008. Specification for the assessment of the life cycle greenhouse gas emissions of goods and services. British Standard, Department for Environment Food and Rural Affairs and Carbon Trust. British Standards Institute, London.

Payraudeau, S., van der Werf, H.M.G., Vertès, F., 2007. Analysis of the uncertainty associated with the estimation of nitrogen losses from farming systems. Agric. Syst. 94, 416-430.

Pelletier, N., Pirog, R., Rasmussen, R., 2010. Comparative life cycle environmental impacts of three beef production strategies in the Upper Midwestern United States. Agric. Syst. 103, 380-389.

Phetteplace, H.W., Johnson, D.E., Seidl, A.F., 2001. Greenhouse gas emissions from simulated beef and dairy livestock systems in the United States. Nutr. Cycl. Agroecosyst. 60, 99-102.

Prudêncio da Silva, V., van der Werf, H.M.G. Spies, A., Soares, S.R., 2010. Variability in environmental impacts of Brazilian soybean according to crop production and transport scenarios. J. Environ. Manage. 91, 1831-1839.

Renting, H., Rossing, W.A.H., Groot, J.C.J., Van der Ploeg, J.D., Laurent, C., Perraud, D., Stobbelaar, D.J., Van Ittersum, M.K., 2009. Exploring multifunctional agriculture. A review of conceptual approaches and prospects for an integrative transitional framework. J. Environ. Manage. 90, S112-S123.

Réseaux d'élevage Charolais, 2004. Poids et prix de vente des animaux charolais en 2004. Available online: http://www.inst-elevage.asso.fr/spip.php? page $=$ article_espace\&id_espace $=9328$ id_article $=7622$.

Réseaux d'élevage Charolais, 2005. Poids et prix de vente des animaux charolais en 2005. Available online: http://www.inst-elevage.asso.fr/IMG/pdf/ CR_090654008.pdf.

Réseaux d'élevage Charolais, 2006. Poids et prix de vente des animaux charolais en 2006. Available online: http://www.inst-elevage.asso.fr/IMG/ pdf_CR_090754010.pdf.

Réseaux d'élevage Charolais, 2007. Poids et prix de vente des animaux charolais en 2007. Available online: http://www.inst-elevage.asso.fr/IMG/pdf_CR_ 090854010.pdf.

Réseaux d'élevage Charolais, 2009. Conjoncture économique des systèmes bovins charolais - Campagne 2008. Available online: http://www. ede63.com/documents/refBV01.pdf.

Ripoll-Bosch, R., De Boer, I.J.M., Bernués, A., Vellinga, T., 2011. Greenhouse gas emissions of Spanish sheep farming systems: allocating between meat production and ecosystem services. Proceeding of 62nd Annual Meeting of European Federation of Animal Science (EAAP), Stavanger, 2011, p. 61.

Sarzeaud, P., Benoteau, G., Bisson, P., Bouet, J.M., Carteron, P., Dimon, P., Galisson, B., Guibert, R., Henry, J.M., 2009. Systèmes bovins viande en Pays de la Loire et Deux-Sèvres-Cas type. Institut de l'Elevage. Available online: http://www.inst-elevage.asso.fr/spip.php?article18396.

Soussana, J.F., Tallec, T., Blanfort, V., 2010. Mitigating the greenhouse gas balance of ruminant production systems through carbon sequestration in grasslands. Animal 4, 334-350.

Steinfeld, H., Gerber, P., Wassenaar, T., Castel, V., Rosales, M., De Haan, C., 2006. Livestock's Long Shadow: Environmental Issues and Options. FAO, Rome, 390 pp.

Van Ranst, G., Fievez, V., Vandewalle, M., De Riek, J., Van Bockstaele, E., 2009. Influence of herbage species, cultivar and cutting date on fatty acid composition of herbage and lipid metabolism during ensiling. Grass For. Sci. $64,196-207$.

Vermorel, M., Jouany, J.P., Eugène, M., Sauvant, D., Noblet, J., Dourmad, J.Y., 2008. Evaluation quantitative des émissions de méthane entérique par les animaux d'élevage en 2007 en France. INRA Prod. Anim. 21, 403-418.

Vertès, F., Simon, J.C., Le Corre, L., Decau, M.L., 1997. Les flux d'azote au pâturage. II - Etude des flux et de leurs effets sur le lessivage. Fourrages 151, 263-280.

Veysset, P., Lherm, M., Bébin, D., 2010. Energy consumption, greenhouse gas emissions and economic performance assessments in French Charolais suckler cattle farms: model-based analysis and forecasts. Agric. Syst. 103, $41-50$.

Veysset, P., Lherm, M., Bébin, D., 2011. Productive, environmental and economic performances assessments of organic and conventional suckler cattle farming systems. Org. Agric. 1, 1-16.

Williams, A.G., Audsley, E., Sandars, D.L., 2006. Determining the environmental burdens and resource use in the production of agricultural and horticultural commodities. Main Report. Department for the Environment, Food and Rural Affairs (DEFRA) Research Project IS0205. Cranfield University and DEFRA, Bedford.

Yan, M.J., Humphreys, J., Holden, N.M., 2011. An evaluation of life cycle assessment of European milk production. J. Environ. Manage. 92, 372-379. 


\section{Effects of type of ration and allocation methods on the environmental impacts of beef-production systems}

Nguyen T.T.H. ${ }^{1,2,3,4}$, van der Werf H.M.G. ${ }^{2,3}$, Eugène M. ${ }^{1}$, Veysset P. $^{1}$, Devun J. ${ }^{4}$, Chesneau G. ${ }^{5}$, Doreau M. ${ }^{1 *}$

(1) INRA, UR1213 Herbivores, F-63122 Saint-Genès-Champanelle, France

(2) INRA, UMR1069 Soil Agro and hydroSystem Spatialisation (SAS), F-35000 Rennes, France

(3) Agrocampus Ouest, F-35000 Rennes, France

(4) Institut de l'Elevage, F-63122 Saint-Genès-Champanelle, France

(5) Valorex, La Messayais, F-35210 Combourtillé, France

*michel.doreau@clermont.inra.f 


\section{Supplementary materials}

Table S1: Description of animal categories, duration in pasture and in housing, and annual ration plan for the Standard (St) and enriched omega-3 FA (O3) suckler cow-calf herds with finishing heifers

\begin{tabular}{|c|c|c|c|c|c|c|c|c|c|c|c|c|c|c|c|c|c|}
\hline \multirow{3}{*}{\multicolumn{2}{|c|}{ Type and number of animal }} & \multirow{2}{*}{\multicolumn{2}{|c|}{$\begin{array}{l}\text { Duration in } \\
\text { pasture (d) }\end{array}$}} & \multirow{2}{*}{\multicolumn{2}{|c|}{$\begin{array}{l}\text { Duration in } \\
\text { housing (d) }\end{array}$}} & \multicolumn{12}{|c|}{ Annual ration per animal category (t DM) } \\
\hline & & & & & & \multicolumn{2}{|c|}{$\begin{array}{l}\text { Grazed } \\
\text { grass }\end{array}$} & \multicolumn{2}{|c|}{ Hay } & \multicolumn{2}{|c|}{$\begin{array}{l}\text { Wrapped } \\
\text { grass silage }\end{array}$} & \multicolumn{2}{|c|}{ Barley grain } & \multicolumn{2}{|c|}{ Wheat grain } & \multicolumn{2}{|c|}{ Mix meal $^{3}$} \\
\hline & & St & $\mathbf{O 3}$ & St & $\mathbf{O 3}$ & St & $\mathbf{O 3}$ & St & $\mathbf{O 3}$ & St & $\mathbf{O 3}$ & St & $\mathbf{O 3}$ & St & $\mathbf{O 3}$ & St & $\mathbf{O 3}$ \\
\hline Cows & 70 & 228 & 228 & 137 & 137 & 199 & 191 & 103 & 53.5 & - & 49.2 & 11.9 & 14.0 & 12.3 & 14.2 & 0.3 & 0.2 \\
\hline Heifers (>24 mo) & 30 & 76 & 46 & 76 & 106 & 8.8 & 4.2 & 16.1 & 10.3 & - & 10.3 & 1.1 & 1.5 & 1.3 & 1.5 & 0.2 & - \\
\hline Heifers $(12-24 \mathrm{mo})^{1}$ & 31 & 228 & 228 & 137 & 137 & 43.6 & 45.7 & 21.2 & 13.0 & - & 12.8 & 3.5 & 2.1 & 3.7 & 2.1 & 0.3 & - \\
\hline Heifers $(<12 \mathrm{mo})$ & 31 & 31 & 61 & 61 & 31 & 3.8 & 7.6 & 9.8 & 2.1 & - & 2.2 & 1.6 & 1.9 & 1.8 & 1.9 & - & - \\
\hline Breeding bulls (>24 mo) & 3 & 228 & 228 & 137 & 137 & 6.2 & 5.8 & 6.7 & 3.4 & - & 3.8 & 0.4 & 0.4 & 0.6 & 0.4 & 0.04 & - \\
\hline Breeding bull $(<24 \mathrm{mo})$ & 1 & 228 & 228 & 137 & 137 & 2.2 & 2.6 & 1.4 & 0.5 & - & 0.5 & 0.4 & 0.3 & 0.4 & 0.3 & 0.04 & - \\
\hline Calves $^{2}$ & 62 & 198 & 168 & 76 & 106 & - & - & - & - & - & - & 4.5 & 4.2 & 10.2 & 9.3 & 4.5 & 4.2 \\
\hline Male pre-finishers & 30 & - & - & 61 & - & - & - & 3.8 & - & - & - & 4.2 & - & 4.2 & - & 1.3 & - \\
\hline Cull cows & 16 & - & - & 102 & 102 & - & - & 13.2 & 0 & - & 13.0 & 5.4 & 5.0 & 5.4 & 5.1 & - & - \\
\hline Growing heifers & 14 & 122 & 122 & 0 & 0 & 12.8 & 13.7 & - & - & - & - & 1.7 & 1.3 & 1.6 & 1.3 & - & - \\
\hline
\end{tabular}

Ione heifer died

${ }^{2}$ one weaned male calf replaced the breeding bull

${ }^{3}$ Mix meal composition: $30 \%$ soybean meal, $40 \%$ rapeseed meal and $30 \%$ sunflower meal 
Table S2: Composition (in \%) of fibre-based concentrate (90.2\% DM) and starch-lipid-based concentrate (88.5\% DM)

\begin{tabular}{lcc}
\hline & $\begin{array}{c}\text { Fibre-based } \\
\text { concentrate }\end{array}$ & $\begin{array}{c}\text { Starch-lipid-based } \\
\text { concentrate }\end{array}$ \\
\hline Wheat & - & 8.6 \\
Barley & 2.5 & 9.7 \\
Maize & & 28.0 \\
Dehydrated beet pulp & 21.5 & 6.0 \\
Dehydrated lucerne & 22.5 & - \\
Wheat bran & 28.0 & - \\
Wheat middlings & 12.5 & 3.0 \\
Soybean meal & - & 2.0 \\
Rape seed meal & 3.5 & 21.4 \\
Croquelin ${ }^{\circ}$ & - & 12.0 \\
Other raw materials & 7.3 & 8.0 \\
Mineral & 2.2 & 1.3 \\
\hline DM:Dry matter & &
\end{tabular}

DM: Dry matter

Croquelin ${ }^{\circledR}$ composition: $50 \%$ extruded linseed, $30 \%$ wheat bran and $20 \%$ sunflower meal 
Table S3: Main inputs used, dry matter yield and nitrate-N emitted for pastures and the major feed crops $^{1}$

\begin{tabular}{|c|c|c|c|c|c|c|c|c|c|c|c|c|c|}
\hline Pasture or crop type & $\begin{array}{c}\mathrm{N} \\
\text { mineral }\end{array}$ & $\begin{array}{c}\mathrm{N} \\
\text { manure }\end{array}$ & $\begin{array}{c}\mathbf{P}_{\mathbf{2}} \mathbf{O}_{\mathbf{5}} \\
\text { (triple } \\
\text { superphos } \\
\text { phate) }\end{array}$ & $\begin{array}{c}\mathbf{K}_{\mathbf{2}} \mathbf{O} \\
\text { (potassium } \\
\text { chloride) }\end{array}$ & $\mathrm{CaO}$ & Seed & $\begin{array}{l}\text { Pesticide } \\
\text { (active } \\
\text { ingredient) }\end{array}$ & Diesel & $\begin{array}{l}\text { Agricultural } \\
\text { machinery }\end{array}$ & $\begin{array}{l}\text { Irrigation } \\
\text { water }\end{array}$ & $\begin{array}{c}\text { Plastic for } \\
\text { wrapped } \\
\text { silage }\end{array}$ & $\begin{array}{c}\text { Yield } \\
(\text { dry } \\
\text { matter })^{2}\end{array}$ & $\begin{array}{c}\text { Nitrate-N } \\
\text { emitted }\end{array}$ \\
\hline & $\mathrm{kg} / \mathrm{ha}$ & $\mathrm{kg} / \mathrm{ha}$ & $\mathrm{kg} / \mathrm{ha}$ & $\mathrm{kg} / \mathrm{ha}$ & $\mathrm{kg} / \mathrm{ha}$ & $\mathrm{kg} / \mathrm{ha}$ & $\mathrm{kg} / \mathrm{ha}$ & $\mathrm{kg} / \mathrm{ha}$ & $\mathrm{kg} / \mathrm{ha}$ & $\mathrm{m}^{3} / \mathrm{ha}$ & $\mathrm{kg} / \mathrm{ha}$ & $\mathrm{kg} / \mathrm{ha}$ & $\mathrm{kg} / \mathrm{ha}$ \\
\hline Permanent grassland for $\mathrm{St}$ & 28 & 27 & 19 & 39 & 167 & 0 & 0 & 30 & 5 & 0 & 0 & 5640 & 20 \\
\hline Temporary grassland for St & 33 & 0 & 28 & 58 & 167 & 6 & 0 & 51 & 13 & 0 & 0 & 8280 & 20 \\
\hline Permanent grassland for $\mathrm{O} 3$ & 28 & 27 & 19 & 39 & 167 & 0 & 0 & 29 & 5 & 0 & 7 & 5640 & 20 \\
\hline Temporary grassland for $\mathrm{O} 3$ & 33 & 0 & 28 & 58 & 167 & 6 & 0 & 50 & 14 & 0 & 12 & 8280 & 20 \\
\hline Wheat & 171 & 7 & 37 & 24 & 167 & 140 & 2.6 & 99 & 23 & 0 & 0 & 5650 & 40 \\
\hline Barley & 129 & 6 & 37 & 26 & 167 & 125 & 2.6 & 100 & 24 & 0 & 0 & 5550 & 40 \\
\hline Silage maize & 57 & 138 & 31 & 29 & 167 & 20 & 1.0 & 91 & 22 & 354 & 16 & 11000 & 40 \\
\hline Soybean from Brazil & 6 & 1 & 80 & 80 & 518 & 53 & 1.7 & 76 & 18 & 0 & 0 & 2708 & 18 \\
\hline Linseed & 70 & 0 & 45 & 25 & 0 & 46 & 0.8 & 90 & 22 & 0 & 0 & 1800 & 40 \\
\hline Sugar beet & 103 & 32 & 68 & 146 & 167 & 2 & 3.4 & 97 & 22 & 99 & 0 & 18070 & 40 \\
\hline Lucerne & 0 & 0 & 119 & 256 & 333 & 8 & 0.9 & 73 & 19 & 0 & 0 & 13970 & 15 \\
\hline
\end{tabular}

St: Standard suckler cow-calf herd with finishing heifers

O3: Suckler cow-calf herd with finishing heifers enriched in omega-3 FAs through pasture and wrapped silage

${ }^{1}$ Data for grassland and all crops concern a one-year period, except for soybean, where data are for a six-month period

${ }^{2}$ Yield of grassland corresponds to the yield obtained when all grass is machine harvested. $23 \%$ and $75 \%$ of the yield of permanent and temporary grassland, respectively, was machine harvested as conserved forage (hay and/or wrapped grass silage). Losses during conservation for both hay and wrapped grass silage were assumed to be $6 \%$ of the initial DM. Grass not harvested as conserved forage was available for ingestion by animals during grazing. For several reasons (selective grazing, trampling of grass, unfavourable weather conditions) a part of the grass grown is not ingested, this "loss" corresponded to $31.5 \%$ of grass dry matter available for grazing. 
Table S4: Environmental impacts due to the production of $1 \mathrm{t}$ of forages ${ }^{1}$ and other feed ingredients

\begin{tabular}{|c|c|c|c|c|c|c|c|}
\hline & & Climate change & $\begin{array}{c}\text { Climate } \\
\text { change/LULUC }\end{array}$ & $\begin{array}{c}\text { Cumulative energy } \\
\text { demand }\end{array}$ & Eutrophication & Acidification & Land occupation \\
\hline & Unit & $\mathrm{kg} \mathrm{CO}{ }_{2} \mathrm{eq}$ & $\mathrm{kg} \mathrm{CO}_{2} \mathrm{eq}$ & MJ & $\mathrm{kg} \mathrm{PO}_{4}{ }^{3-} \mathrm{eq}$ & $\mathrm{kg} \mathrm{SO}_{2} \mathrm{eq}$ & ha*a \\
\hline Hay from St permanent grassland & $\mathrm{t} \mathrm{DM}$ & 365 & 227 & 1531 & 3.0 & 4.3 & 0.189 \\
\hline Grazed grass from St permanent grassland & $\mathrm{t} \mathrm{DM}$ & 433 & 243 & 1017 & 4.0 & 5.5 & 0.259 \\
\hline Hay from St temporary grassland & $\mathrm{t} D M$ & 198 & 151 & 1098 & 1.7 & 1.5 & 0.129 \\
\hline Grazed grass from St temporary grassland & $\mathrm{t} D M$ & 231 & 167 & 863 & 2.3 & 1.9 & 0.177 \\
\hline Hay from $\mathrm{O} 3$ permanent grassland & $\mathrm{t} \mathrm{DM}$ & 367 & 229 & 1509 & 3.0 & 4.3 & 0.189 \\
\hline Wrapped silage from $\mathrm{O} 3$ permanent grassland & $\mathrm{t} \mathrm{DM}$ & 405 & 267 & 2771 & 3.0 & 4.5 & 0.189 \\
\hline Grazed grass from $\mathrm{O} 3$ permanent grassland & $\mathrm{t} \mathrm{DM}$ & 438 & 248 & 1017 & 4.0 & 5.6 & 0.259 \\
\hline Hay from $\mathrm{O} 3$ temporary grassland & $\mathrm{t} \mathrm{DM}$ & 199 & 152 & 1085 & 1.7 & 1.5 & 0.129 \\
\hline Wrapped silage from $\mathrm{O} 3$ temporary grassland & $\mathrm{t} \mathrm{DM}$ & 214 & 167 & 1575 & 1.7 & 1.6 & 0.129 \\
\hline Grazed grass from $\mathrm{O} 3$ temporary grassland & $\mathrm{t} \mathrm{DM}$ & 234 & 170 & 862 & 2.3 & 1.9 & 0.177 \\
\hline Wheat & $\mathrm{t} \mathrm{DM}$ & 551 & 551 & 3507 & 4.5 & 4.9 & 0.163 \\
\hline Barley & $\mathrm{t} \mathrm{DM}$ & 475 & 475 & 3208 & 4.2 & 4.0 & 0.166 \\
\hline Maize silage & $\mathrm{t} \mathrm{DM}$ & 279 & 279 & 1644 & 2.6 & 2.6 & 0.092 \\
\hline Starch-lipid-based concentrate ${ }^{2}$ & $\mathrm{t} D M$ & 587 & 606 & 6344 & 4.9 & 4.3 & 0.128 \\
\hline Fibre-based concentrate ${ }^{2}$ & $\mathrm{t} D M$ & 685 & 686 & 9454 & 2.4 & 4.0 & 0.109 \\
\hline Mix meals ${ }^{3}$ & $\mathrm{t} \mathrm{DM}$ & 566 & 851 & 7416 & 5.0 & 4.6 & 0.167 \\
\hline Dehydrated lucerne & $\mathrm{t} D M$ & 961 & 961 & 14660 & 1.2 & 4.5 & 0.074 \\
\hline Dehydrated beet pulp & $\mathrm{t} \mathrm{DM}$ & 902 & 902 & 14430 & 0.6 & 4.7 & 0.012 \\
\hline Croquelin ${ }^{\circledR}$ & $\mathrm{t} \mathrm{DM}$ & 686 & 686 & 6461 & 9.0 & 5.3 & 0.177 \\
\hline
\end{tabular}

St: Standard suckler cow-calf herd with finishing heifers

O3: Suckler cow-calf herd with finishing heifers enriched in omega-3 FAs through pasture and wrapped silage

DM: dry matter

SCL: Bull-fattening herd using a starch-based concentrate supplemented with linseed 
FC: Bull-fattening herd using a fibre-based concentrate diet

${ }^{1}$ Impacts correspond to ingested forages and grazed grass from grassland

${ }^{2}$ See composition in Table S3

${ }^{3}$ Mix meal composition: $30 \%$ soybean meal, $40 \%$ rapeseed meal and $30 \%$ sunflower meal

Croquelin ${ }^{\circledR}$ composition: $50 \%$ extruded linseed, $30 \%$ wheat bran and $20 \%$ sunflower meal 
Table S5: Impacts per ha of two suckler cow-calf herds with finishing heifers and four bull-fattening herds

\begin{tabular}{llcccccc}
\hline & & \multicolumn{3}{c}{$\begin{array}{c}\text { suckler cow-calf herd } \\
\text { with finishing heifers }\end{array}$} & \multicolumn{3}{c}{ Bull-fattening herd } \\
\cline { 3 - 8 } & & $\mathrm{St}$ & $\mathrm{O} 3$ & $\mathrm{SM}$ & $\mathrm{SML}$ & $\mathrm{FC}$ & $\mathrm{SCL}$ \\
\hline Climate change & $\mathrm{t} \mathrm{CO}_{2}$ eq & 5.5 & 5.5 & 11.1 & 10.8 & 24.9 & 10.1 \\
Climate change/LULUC & $\mathrm{t} \mathrm{CO}_{2}$ eq & 4.9 & 4.9 & 12.2 & 11.8 & 24.9 & 10.2 \\
Cumulative energy demand & $\mathrm{GJ}_{\text {Eutrophication }}$ & 11.8 & 12.4 & 42.6 & 43.4 & 160.6 & 61.9 \\
Acidifcation & $\mathrm{kg} \mathrm{PO}_{4}{ }^{3-}$ eq & 19 & 19 & 42 & 45 & 53 & 53 \\
\hline
\end{tabular}

St: Standard suckler cow-calf herd with finishing heifers

O3: Suckler cow-calf herd with finishing heifers enriched in omega-3 FAs through pasture and wrapped grass silage

SM: Standard bull-fattening herd using a diet rich in starch based on maize silage

SML: Bull-fattening herd using a diet rich in starch (based on maize silage) supplemented with linseeds

FC: Bull-fattening herd using a fibre-based concentrate diet

SCL: Bull-fattening herd using a starch-based concentrate supplemented with linseeds

LULUC: Land use and land use change 
Table S6: Eutrophication (EP), Acidification (AP) and Land occupation (LO) per $\mathrm{kg}$ of carcass mass of four animal types delivered from the four production systems according to four allocation methods

\begin{tabular}{|c|c|c|c|c|c|c|c|c|c|c|}
\hline & \multicolumn{4}{|c|}{ Fattened bull } & \multicolumn{2}{|c|}{ Finished heifer } & \multicolumn{2}{|c|}{ Finished cull cow } & \multicolumn{2}{|c|}{ Breeding bull } \\
\hline & St-SM & O3-SML & St-FC & O3-SCL & St & $\mathbf{O 3}$ & St & $\mathbf{O 3}$ & St & $\mathbf{O 3}$ \\
\hline & \multicolumn{10}{|c|}{$\mathrm{EP}\left(\mathrm{g} \mathrm{PO}_{4}{ }^{3-} \mathrm{eq} / \mathrm{kg}\right.$ carcass mass $)$} \\
\hline Mass allocation & 81 & 82 & 72 & 82 & 110 & 108 & 120 & 119 & 115 & 114 \\
\hline Protein allocation & 91 & 92 & 82 & 92 & 119 & 118 & 100 & 99 & 56 & 55 \\
\hline Economic allocation & 94 & 95 & 85 & 95 & 113 & 112 & 98 & 97 & 71 & 70 \\
\hline Economic allocation with subsidies & \multicolumn{10}{|c|}{$\mathrm{AP}\left(\mathrm{g} \mathrm{SO}_{2}\right.$ eq $/ \mathrm{kg}$ carcass mass $)$} \\
\hline Mass allocation & 144 & 147 & 141 & 147 & 182 & 186 & 204 & 207 & 189 & 194 \\
\hline Protein allocation & 160 & 163 & 157 & 163 & 198 & 202 & 171 & 174 & 92 & 94 \\
\hline Economic allocation & 165 & 169 & 162 & 169 & 188 & 191 & 167 & 170 & 117 & 119 \\
\hline \multirow[t]{2}{*}{ Economic allocation with subsidies } & 155 & 158 & 152 & 159 & 170 & 173 & 153 & 156 & 106 & 109 \\
\hline & \multicolumn{10}{|c|}{$\mathrm{LO}\left(\mathrm{m}^{2} \mathrm{a} / \mathrm{kg}\right.$ carcass mass $)$} \\
\hline Protein allocation & 40.6 & 39.6 & 37.8 & 38.6 & 64.2 & 63.4 & 50.7 & 49.5 & 29.7 & 29.2 \\
\hline Economic allocation & 42.3 & 41.3 & 39.5 & 40.3 & 61.0 & 60.2 & 49.4 & 48.3 & 37.7 & 37.1 \\
\hline Economic allocation with subsidies & 39.1 & 38.2 & 36.3 & 37.1 & 55.2 & 54.5 & 45.2 & 44.2 & 34.2 & 33.7 \\
\hline
\end{tabular}

St: Standard suckler cow-calf herd with finishing heifers

O3: Suckler cow-calf herd with finishing heifers enriched in omega-3 FAs through pasture and wrapped silage

SM: Standard bull-fattening herd using a diet rich in starch based on maize silage

SML: Bull-fattening herd using a diet rich in starch (based on maize silage) supplemented with linseeds

FC: Bull-fattening herd using a fibre-based concentrate diet

SCL: Bull-fattening herd using a starch-based concentrate supplemented with linseed 
Table S7: Impacts of beef meat product (per kg of carcass mass) delivered from the four beef-production systems and of activities for maintaining ecosystem services (per ha of grassland) from two suckler cow-calf herds with finishing heifers using economic allocation with agro-environmental subsidies

\begin{tabular}{|c|c|c|c|c|c|c|}
\hline & \multicolumn{4}{|c|}{ Beef } & \multicolumn{2}{|c|}{$\begin{array}{c}\text { Activities for maintaining } \\
\text { ecosystem services }\end{array}$} \\
\hline & St-SM & O3-SML & St-FC & O3-SCL & St & $\mathrm{O} 3$ \\
\hline & \multicolumn{4}{|c|}{ per kg carcass mass } & \multicolumn{2}{|c|}{ per ha of grassland } \\
\hline Climate change $\left(\mathrm{kg} \mathrm{CO}_{2} \mathrm{eq}\right)$ & 25.6 & 25.6 & 25.8 & 24.8 & 557 & 563 \\
\hline Climate change/LULUC $\left(\mathrm{kg} \mathrm{CO}_{2} \mathrm{eq}\right)$ & 23.6 & 23.6 & 23.4 & 22.5 & 495 & 501 \\
\hline Cumulative energy demand (MJ) & 60.2 & 63.6 & 68.8 & 66.3 & 1192 & 1261 \\
\hline Eutrophication $\left(\mathrm{g} \mathrm{PO}_{4}{ }^{3-} \mathrm{eq}\right)$ & 91 & 91 & 86 & 91 & 1984 & 1966 \\
\hline Acidification $\left(\mathrm{g} \mathrm{SO}_{2} \mathrm{eq}\right)$ & 157 & 160 & 155 & 160 & 3293 & 3367 \\
\hline Land occupation $\left(\mathrm{m}^{2} \mathrm{a}\right)$ & 44.0 & 43.2 & 42.6 & 42.7 & 1052 & 1039 \\
\hline
\end{tabular}

St: Standard suckler cow-calf herd with finishing heifers

O3: Suckler cow-calf herd with finishing heifers enriched in omega-3 FAs through pasture and wrapped silage

SM: Standard bull-fattening herd using a diet rich in starch based on maize silage

SML: Bull-fattening herd using a diet rich in starch (based on maize silage) supplemented with linseeds

FC: Bull-fattening herd using a fibre-based concentrate diet

SCL: Bull-fattening herd using a starch-based concentrate supplemented with linseeds 